\title{
BRIÓFITAS DO PARQUE NACIONAL DE SETE QUEDAS, GUAÍRA, PR, BRASIL ${ }^{1}$
}

\author{
Olga Yano ${ }^{2}$ \\ Austher G. Colletes ${ }^{2}$
}

Recebido em 24/06/1999. Aceito em 04/04/2000

\begin{abstract}
RESUMO - (Briófitas do Parque Nacional de Sete Quedas, Guaíra, PR, Brasil). Foram encontradas no Parque 65 espécies de briófitas, sendo 24 (14 novas para o Estado) de Hepatophyta, distribuídas em seis famílias e 14 gêneros, 41 espécies (sendo 12 novas para o Estado) de Bryophyta em 23 famílias e 30 gêneros e Erytrophyllastrum andinum (Sull.) Zand. nova para o Brasil. As famílias que apresentaram maior número de espécies foram Lejeuneaceae com 15 e Fissidentaceae com cinco, Meteoriaceae, Frullaniaceae e Bryaceae com quatro. São apresentados descrições e comentários para todas as espécies e ilustrações para algumas.
\end{abstract}

Palavras-chave - Bryophyta, Hepatophyta, Parque Nacional de Sete Quedas, Brasil

\begin{abstract}
Bryophytes from the National Park of Sete Quedas, Guaíra, Paraná, Brazil). Sixty-five species of bryophytes were found in the National Park of "Sete Quedas", Guaira, Paraná, Brazil: Hepatophyta with 24 species (with 14 species new to State) arranged in six families and 14 genera; Bryophyta with 41 species (with 12 new to the State) arranged in 23 families and 30 genera, being Erythrophyllastrum andinum (Sull.) Zand. new for Brazil. The families most represented are Lejeuneaceae with 15 species, Fissidentaceae with five, Meteoriaceae, Frullaniaceae and Bryaceae with four each. Description and comments for each species and illustrations for some species are presented.
\end{abstract}

Key words - Bryophyta, Hepatophyta, National Park of Sete Quedas, Brazil

\section{Introdução}

O Parque Nacional de Sete Quedas localizava-se no município de Guaíra (24 $4^{\prime} \mathrm{S}, 54^{\circ}$ 11 'W), no Estado do Paraná. Possuía área de 233 ha, onde sua maior atração era o turismo, em virtude de sete grandes quedas d'água, de beleza exuberante, as quais dividiam-se em várias outras quedas menores que se estendiam ao longo do Rio Paraná, que cortava o Parque.
Na área do Parque não foram realizados trabalhos sobre as briófitas, embora para o Estado do Paraná existam alguns como o de Sehnem (1969), que trata os musgos para a região sul brasileira e, mais recentemente, de Hirai et al. (1998), além de trabalhos de briófitas para o Brasil, como o de Yano (1992a).

Em setembro/1982, após a construção da represa de Itaipu, tendo as águas do rio sido represadas, toda a área do parque foi inundada.

1 Auxílio FAPESP para coleta (Proc. n. 82/0002-3)

2 Instituto de Botânica, C. Postal 4005, CEP 01061-970, São Paulo, SP, Brasil 
Seis meses antes da inundação, foram feitas coletas na região, com o objetivo de conhecer a brioflórula da área, ampliando os dados de distribuição geográfica das briófitas para o Brasil.

\section{Material e métodos}

$\mathrm{O}$ material foi coletado aleatoriamente em trilhas já existentes no parque e áreas próximas às quedas d'águas.

A metodologia de coleta e herborização do material briofítico seguiram as descritas por Yano (1984a).

A identificação do material foi baseada nos trabalhos de Bartram (1949), Florschütz (1964), Bischler (1969), Hell (1969), Sehnem (1969), Stotler \& Crandall-Stotler (1974), Fulford (1976), Manuel (1977), Gier (1980), LemosMichel (1980, 1999), Ochi (1980), Schuster (1980), Crum \& Anderson (1981), Tixier (1985), Vianna (1985), Buck \& Ireland (1985), Frahm (1991), Yano (1992a), Lisboa (1993), Zander (1993) e Sharp et al. (1994).

O sistema de classificação para Bryophyta baseia-se em Vitt (1984) e para Hepatophyta, em Schuster (1984).

A distribuição geográfica brasileira das espécies foi baseada em Yano (1981, 1984b, 1989, 1995).

O material coletado encontra-se depositado no Herbário Científico do Estado "Maria Eneyda P. Kauffmann Fidalgo," do Instituto de Botânica (SP). Assim, na citação do material examinado apenas são mencionados substrato, data da coleta, coletor(es) e número de SP.

\section{Resultados e discussão}

Foram coletadas 119 amostras de briófitas, tendo sido encontradas 65 espécies: 24 Hepaticopsida (Hepatophyta) distribuídas em seis famílias, as quais apresentam 14 gêneros; 41 Bryopsida (Bryophyta) distribuídas em 23 famílias e 30 gêneros, relacionadas a seguir em ordem alfabética de família.
Bryophyta

Amblystegiaceae

Austinia tenuinervis (Mitt.) C. Muell., Linnaea 39: 440. 1875.

Basiônimo: Hypnum tenuinerve Mitt., J. Linn. Soc. Bot. 12: 549.1869.

Tipo: Cuba, Wright 65.

Ilustrações: Sharp et al. (1994).

Gametófitos pequenos, verdes ou amarelos; filídios 2,5-4,5 mm compr., oblongo-lanceolados geralmente gradualmente longo-acuminados, costa fina até mais ou menos $3 / 4$ do filídio; células medianas do filídio alongadas passando a romboidais no ápice, células da base longo-retangulares. Seta 10-30mm compr., cápsula 1,02,5mm compr.

Material examinado: sobre tronco de árvore viva, 20/III/1982, Yano 4059p.p. (SP 171890).

Comentários: geralmente encontrada sobre troncos, mas pode também crescer sobre outros tipos de substrato. Caracteriza-se pelo filídio oblongo-lanceolado, com costa fina até $3 / 4$ do seu comprimento e as células basais longo-retangulares.

Ocorre no Estado de São Paulo. É a primeira referência para o Paraná.

\section{Bartramiaceae}

Philonotis glaucescens (Hornsch.) Broth., Bih. K. Svensk. Vetensk Akad. Handl. 21 Afd. 3(3): 27. 1895.

Basiônimo: Bartramia glaucescens Hornsch., Flora Brasil. 1(2): 40.1840.

Tipo: Brasil, Rio de Janeiro, prope Sebastianópolis, Beyrich.

Ilustrações: Crum \& Anderson (1981).

Gametófitos pequenos, verde-claros; filídios subfalcados, menor que $1 \mathrm{~mm}$ compr., lanceolado-acuminados, costa percurrente, margem recurvada; células lineares, oblongas; seta 1,0-1,5cm, cápsula inclinada, ovóide.

Material examinado: sobre pedra úmida em corredeira de água, 17/III/1982, Yano 3987 (SP 
171841); idem, sobre casca de árvore viva, $17 /$ III/1982, Yano 4013 (SP 171859); idem, ilha perto do salto 17 , sobre frestas de pedra escorrendo água, 18/III/1982, Yano 4051(SP 171883).

Comentários: cresce geralmente sobre rochas, mas às vezes também sobre árvores. Caracteriza-se pelo filídio pequeno com costa percurrente e margens recurvadas.

Ocorre nos Estados do Amazonas, Minas Gerais, Mato Grosso, Paraná, Rio Grande do Sul, Rio de Janeiro, Santa Catarina e São Paulo.

\section{Bryaceae}

Bryum apiculatum Schwaerg., Spec. Musc. Suppl. 1(2): 102.72. 1816.

Tipo: América Meridional (G).

Ilustrações: Sharp et al. (1994).

Gametófitos medianos, lustrosos, ocasionalmente avermelhados ou castanhos; filídios fortemente côncavos, oblongos a oblongolanceolados, pequenos ou longo-apiculados; margem plana, costa excurrente; células oblongo-rômbicas, estreitando-se abruptamente no ápice; seta entre 2-3 compr.; cápsula horizontal $\pm 3 \mathrm{~mm}$ compr.

Material examinado: Salto 14 , no solo úmido da mata, 17/III/1982, Yano 3972 (SP 171832).

Comentários: cresce geralmente sobre rocha ou solo seco, às vezes úmido; caracterizase pela cor avermelhada ou amarronzada, lustrosa, filídios apiculados, costa excurrente e tamanho da seta entre $2-3 \mathrm{~cm}$ compr.

Ocorre nos Estados da Bahia, Paraíba, Maranhão, Rio de Janeiro, Rio Grande do Sul, Santa Catarina e São Paulo; Amazonas, Minas Gerais, como B. cruegeri. É a primeira referência para o Paraná.

Bryum duplicatum Broth., Bih. K. Svensk. VetenskAkad. Handl. 26 Afd.3(7): 29. 1900. Tipo: Brasil.

Ilustrações: Ochi (1980).

Gametófitos robustos; filídios flexuosos, eretos quando secos, extensos, \pm curvados em- baixo quando úmidos, oblongos ou oblongoespatulados, mais de 4,6mm compr., ápice pouco acuminado, margem revoluta, plana e denticulada; costa fraca, pouco excurrente, dentes duplos no ápice; células rombo-hexagonais ou simplesmente hexagonais, retangular na parte basal. Esporófito não observado.

Material examinado: sobre pedra escorrendo água perto do salto, 17/III/1982, Yano 3990p.p. (SP 171843).

Comentários: pode ser encontrada principalmente sobre rochas ou às vezes sobre troncos; caracteriza-se pelos dentes duplos no ápice marginal do filídio.

Ocorre nos Estados da Paraíba, Rio de Janeiro, Rio Grande do Sul, Santa Catarina, e São Paulo. É a primeira referência para o Estado do Paraná.

Bryum limbatum C. Muell., Syn. Musc. Frond. 2: 573.1851.

Tipo: Costa Rica.

Ilustrações: Oliveira e Silva (1998).

Gametófitos pequenos, verde-claros, filídios ovalados ou oblongos, ápice arredondado, obtuso ou agudo, brevemente acuminado; borda distinta, 4-5 fileiras de células longas; margem inteira ou finamente crenulada, costa fina, subpercurrente a pouco excurrente; células pequenas, regularmente hexagonais no meio da lâmina, retangulares na base; costa terminando depois do ápice do filídio; seta $\pm 1 \mathrm{~cm}$ compr. Cápsula \pm assimétrica, ereta a horizontal.

Material examinado: área militar, no solo úmido da mata, 20/III/1982, Yano 4066 (SP 171891).

Comentários: pode ser encontrada sobre solo bem como sobre rochas; caracteriza-se pela presença de 4-5 fileiras de células alongadas na borda do filídio.

Ocorre nos Estados do Espírito Santo, Minas Gerais, Paraná, Rio Grande do Sul, Rio de Janeiro e Santa Catarina.

Bryum pseudo-marginatum Geh. \& Hampe, Flora 64: 375.1881. 
Tipo: Brasil.

Ilustrações: Ochi (1980).

Gametófitos grandes, \pm lustrosos; filídios robustos, crispados quando secos, oblongos a oblongo-lanceolados; margem revoluta do meio para a base, denticulada, dentes irregulares, margem bordeada indistintamente por 1-2 fileiras de células. Seta de $3-5 \mathrm{~cm}$ compr. Cápsula pêndula, oblonga, piriforme, 4-5mm compr.

Material examinado: Ilha perto do salto 17 , sobre pedra úmida, 18/III/1982, Yano 4050 (SP 171882).

Comentários: caracteriza-se pela presença de 1-2 fileiras de células bordeando a margem. Ocorre nos Estados do Paraná, Rio de Janeiro, Santa Catarina e São Paulo.

Callicostaceae

Lepidopilum mosenï Broth., Bih. K. Svenska VetenskAkad. Handl. 21 Afd. 3(3): 34. 1895. Tipo: Brasil, São Paulo, Serra de Caracol, Mosén 266.

\section{Fig. 1a-e}

Gametófitos grandes, verde-escuros; filídios $\pm 4 \mathrm{~mm}$ compr., filídio lateral divergente, assimétrico, oblongo, ápice finamente crenulado; margem inteira; costa dupla no terço basal; células hexagonais, elípticas; seta $7 \mathrm{~mm}$ compr., avermelhada, cápsula oval, paleácea, peristômio duplo.

Material examinado: sobre o solo humoso, úmido, 17/III/1982, Yano 4022, det. W.R. Buck (SP 171865).

Comentários: pode ser encontrada tanto sobre troncos como sobre solo; caracteriza-se pelo filídio oblongo, crenulado no ápice; células elípticas e costa dupla no terço basal.

Já verificado apenas no Estado de São Paulo. É a primeira referência para o Estado do Paraná.

Schizomitrium pallidum (Hornsch.) Crum \& Anderson, Mosses of Eastern North America 2: 822. 1981.

Basiônimo: Hookeria pallida Hornsch. in Mart.,
Flora Brasil. 1(2): 64. 1840.

Tipo: Brasil.

Ilustrações: Crum \& Anderson (1981).

Gametófitos pequenos, prostrados; filídios dispostos lateralmente em duas fileiras, verdeopacos a amarelos; complanados, oblongos, apiculados; margem serrulada no ápice; costa dupla; células do ápice irregulares; células hexagonais isodiamétricas, unipapilosas nas duas faces. Seta 6-8mm compr., cápsula inclinada a horizontal, $1 \mathrm{~mm}$ compr., oblongo-cilíndrica.

Material examinado: sobre tronco podre na mata, 17/III/1982, Yano 4003(SP 171853); idem, sobre pau podre na mata, 17/III/1982, Yano 4028 (SP 171868).

Comentários: geralmente encontrada sobre tronco em decomposição; caracteriza-se pela cor verde-opaca a amarelo-clara, a disposição lateral dos filídios em duas fileiras, a costa dupla, com o filídio oblongo-apiculado e as células hexagonais com uma papila em ambas as faces.

Ocorre nos Estados do Acre, Amazonas, Amapá, Espírito Santo, Goiás, Minas Gerais, Mato Grosso, Pará, Paraná, Pernambuco, Rio de Janeiro, Roraima, Rondônia, São Paulo e Sergipe; Bahia (Bastos \& Yano 1993).

\section{Calymperaceae}

Calymperes lonchophyllum Schwaegr., Spec. Musc. Frond. Suppl. 1(2): 333. 1816.

Tipo: Guiana.

Ilustrações: Lisboa (1993).

Gametófitos medianos, $10-17 \mathrm{~mm}$ alt., verde-claros a verde-escuros; filídios longo-lineares, crispados, tortuosos quando secos, com a base elíptica ou estreitamente obovada, formando uma bainha $10-15 \mathrm{~mm}$ alt. ápice agudo; costa subexcurrente a percurrente, terminando no ápice ou poucas células abaixo; margem da lâmina superior espessada em sua maior parte duplamente serrulada; células da lâmina estreitas que podem variar de oval-circular ou oblonga, células inferiores de dois tipos: cancelinas quadradas a retangulares ou arredondadas e as células 


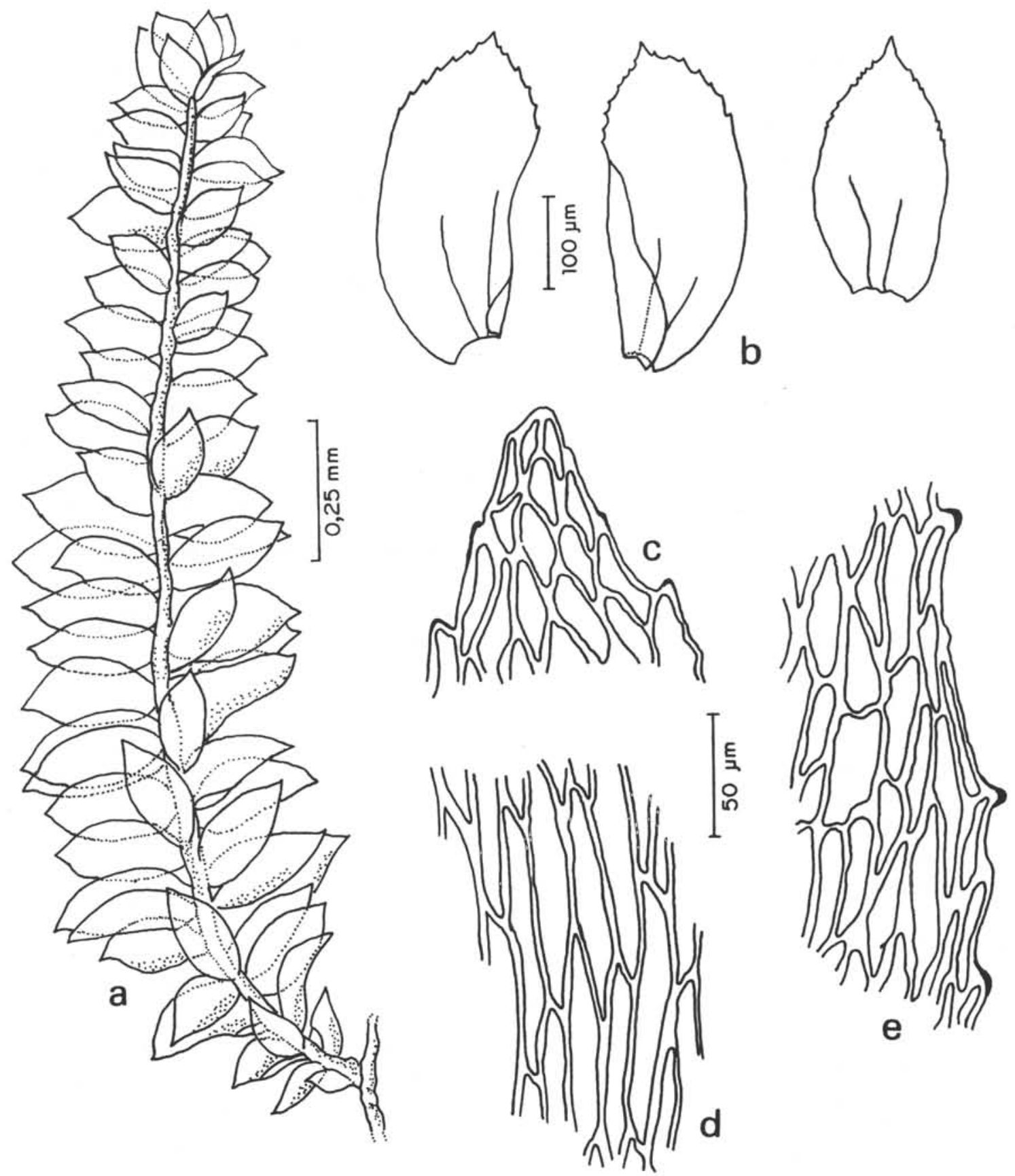

Figuras1a-e. Lepidopilum mosenii Broth. a. aspecto geral do gametófito; b. filídios bicostados; c: células do ápice do filídio; d. células do centro-basal do filídio; e. células da margem do filídio. (Yano 4022). 
longo-lineares na margem.

Material examinado: sobre pedra escorrendo água perto do salto 14, 17/III/1982, Yano 3990p.p. (SP 171843); idem, sobre tronco de árvore viva, 17/III/1982, Yano 3992(SP 171845).

Comentários: pode tanto ser encontrado sobre tronco como sobre rocha; caracteriza-se pelos filídios muito longos, lineares e crispados, tortuosos quando secos.

Ocorre nos Estados do Acre, Alagoas, Amazonas, Amapá, Bahia, Espírito Santo, Maranhão, Mato Grosso, Pará, Pernambuco, Rio de Janeiro, Rondônia, Roraima e São Paulo. É a primeira referência para o Estado do Paraná.

\section{Dicranaceae}

Campylopus griseus (Hornsch.) Jaeg., Ber. St. Gall. Naturw. Ges. 1870-71: 443. 1872.

Basiônimo: Thysanomitrium griseum Hornsch. in Mart., Flora Brasil.1: 16. 1840.

Tipo: Uruguai, Montevideo.

Ilustrações: Frahm (1991).

Gametófitos robustos, verde-amarelados a mais escuros; filídios 7-8mm compr. bem recurvado no ápice; costa excurrente, longa, serreada; ápice hialino, lameloso dorsalmente; células alares infladas, margem bordeada por uma camada de células hialinas, células do ápice ovais. Esporófito não visto.

Material examinado: Ilha perto do salto 17 , sobre pedras úmidas, 18/III/1982, Yano 4044 (SP 171876)

Comentário: geralmente cresce sobre rochas, mas também pode ser encontrada no solo; caracteriza-se pelo ápice do filídio bem recurvado e hialino e também pelas células hialinas da borda.

Ocorre nos Estados do Espírito Santo, Minas Gerais, Paraná, Piauí, Rio Grande do Sul, Santa Catarina e São Paulo.

Entodontaceae

Entodon macropodus (Hedw.) C. Muell., Linnaea 18: 707. 1845.
Basiônimo: Neckera macropoda Hedw., Spec. Musc. Frond. 207. 1801.

Tipo: América meridional.

Ilustrações: Sharp et al. (1994).

Gametófitos pequenos, verde-claros; filídios fortemente complanados, longolanceolados; margem levemente serrulada no meio, aumentando até o ápice; células medianas do filídio alongadas, arredondando-se em direção à base. Seta 13-303mm compr., cápsula 2-4mm compr.

Material examinado: Salto 14, sobre raízes e no solo úmido, 17/III/1982, Yano 3970 (SP 171830).

Comentários: geralmente encontrada sobre solo, mas ocasionalmente 0também em troncos e rochas; caracteriza-se pelas células alongadas no filídio e arredondadas na base.

Ocorre apenas no Estado do Paraná.

Erythrodontium longisetum (Hook.) Par., Ind. Bryol. 436. 1896.

Basiônimo: Neckera longiseta Hook., Musc. Exot. 43.1818.

Tipo: Peru.

Ilustrações: Oliveira e Silva (1998).

Gametófitos amarelo-esverdeados; filídios imbricados, 1,0-1,5 mm compr., oblongoobovados, abruptamente acuminados, côncavos, minutamente denteados, sem costa ou costa curta simples ou dupla; seta amarela $1,5-2,5 \mathrm{~cm}$ compr., cápsula oblongo-cilíndrica $\pm 3 \mathrm{~mm}$ compr.

Material examinado: sobre tronco de árvore viva, 17/III/1982, Yano 3996p.p. (SP 171847); idem, sobre pedras grandes perto do salto 17 , 18/III/1982, Yano 4039(SP 171873); idem, ilha perto do salto 17 , sobre pedras formando tapete, 18-III-1982, Yano 4048 (SP 171880); idem, área militar, sobre tronco de árvore viva, 20/III/ 1982, Yano 4071 (SP 171895).

Comentários: pode ser encontrada tanto sobre tronco, raízes, como sobre pedra; caracteriza-se principalmente pela longa seta amarela.

Ocorre nos Estados de Minas Gerais, 
Paraná, Pernambuco, Rio Grande do Sul e São Paulo.

\section{Fissidentaceae}

Fïssidens amoenus C. Muell., Bot. Zeitung 5: 38. 1847.

Tipo: Brasil, Santa Catarina, col. Pabst (neotipo S). Ilustrações: Lisboa (1993, como F. prionodes var. puiggarii).

Gametófitos pequenos, 1-5mm compr., verdes; filídios oblongo-lanceolados $0,5-0,8 \mathrm{~mm}$ compr., costa percurrente a subpercurrente, terminando poucas células abaixo do ápice; ápice agudo; células irregularmente hexagonais, paredes finas, unipapilosas ou unimamilosas, algumas lisas; lâmina vaginante até $1 / 2$ do filídio. Seta $2,5 \mathrm{~mm}$ compr., cápsula ovalado-cilíndrica $0,3-0,5 \mathrm{~mm}$ compr.

Material examinado: sobre casca de árvore viva, 17/III/1982, Yano 4026 (SP 171866)

Comentários: pode ser encontrada em vários tipos de substrato, tais como solo, rocha ou tronco; caracteriza-se por apresentar na maioria dos filídios costa percurrente ou às vezes subpercurrente, associadas a células pequenas, claras com papilas ou às vezes ausente.

Ocorria apenas no Estado de Rondônia. É a primeira referência para o Estado do Paraná.

Fïssidens brevipes Besch., J. Bot. 5: 252. 1891. Tipo: Paraguai (NY).

Ilustrações: Sharp et al. (1994).

Gametófitos amarelados a verde-claros; filídios oblongo-ovalados, ápice obtuso, arredondado ou pouco obtuso, acuminado, margem inteira ou finamente crenulada, mais de $1,5 \mathrm{~mm}$ compr., lamina vaginante de $2 / 3$ a $3 / 4$ do filídio; lâmina dorsal cônica, freqüentemente convexa, terminando bem acima da inserção, células irregulares hexagonais, mamilosas, retangulares perto da base da lâmina vaginante e perto da costa; costa forte, terminando algumas células antes do ápice. Seta terminal, mais de $2 \mathrm{~mm}$ compr. Cápsula ereta, ovóide, $0,5 \mathrm{~mm}$ compr.
Material examinado: na base do tronco de árvore, 19/III/1982, Yano 4056 (SP 171887).

Comentários: geralmente cresce sobre troncos, caracteriza-se pela lâmina dorsal cônica ou convexa, terminando bem antes da inserção, e ápice bem arredondado.

Ocorre nos Estados de Minas Gerais, Paraná, Rio Grande do Sul, Santa Catarina e São Paulo.

Fissidens bryoides Hedw., Spec. Musc. Frond. 153. 1801.

Tipo: San Carlos, (NY).

Ilustração: Yano \& Oliveira e Silva (1997).

Gametófitos pequenos, 0,5-1,0mm alt., verdes a verde-escuros, filídios oblongolanceolados a oblongo-ligulados, ápice obtuso a agudo, apiculado, margem inteira, bordeada por células linear-alongadas, hialinas até quase o ápice; lâmina vaginante $2 / 3$ do filídio; costa forte, percurrente, células superiores irregularmente quadráticas a hexagonais. Seta terminal $3,0-3,5 \mathrm{~mm}$ compr., castanha; cápsula $0,1-0,5 \mathrm{~mm}$ compr.

Material examinado: área militar, sobre arenito na margem do riacho, 20/III/1982, Yano 4075 (SP 171896); idem, sobre húmus na base de árvore, 17/III/1982, Yano 4032p.p. (SP 174214).

Comentários: pode ser encontrada sobre solo e rochas em lugares úmidos e sombreados, às vezes sobre troncos; caracteriza-se por apresentar células hialinas na borda e o filídio oblongo-lanceolado a oblongo-ligulado.

Ocorre nos Estados do Paraná, Rio de Janeiro, Roraima, São Paulo e Arquipélago Fernando de Noronha (PE).

Fissidens mollis Mitt., J. Linn. Soc. Bot. 12: 600. 1869.

Tipo: Jamaica.

Ilustrações: Lisboa (1993).

Gametófitos pequenos, $0,5-0,8 \mathrm{~mm}$ compr., verde-claros; filídios lineares a oblongo- 
lanceolados, 0,3-0,4 $\mathrm{mm}$ compr.; ápice agudo, margens inteiras, fortemente bordeadas por células longas, levemente serreadas no ápice; lâmina vaginante $1 / 2$ do filídio; costa fina geralmente terminando pouco abaixo do ápice; células superiores laxas, hexagonais, células inferiores longo-retangulares. Seta 4$6 \mathrm{~mm}$ compr., cápsula ereta ou inclinada, ovalada $0,5-1 \mathrm{~mm}$ compr.

Material examinado: sobre pedra escorrendo água perto do salto, 17/III/1982, Yano 3989 (SP 171842); idem, no solo úmido junto de árvore, 17/III/1982, Yano 4010p.p. (SP 171857); idem, sobre húmus na base de árvore, 17/III/1982, Yano 4032p.p. (SP 174214).

Comentários: o habitat muito característico dessa espécie é ambiente bem úmido, sendo encontrada sobre rocha e argila; caracteriza-se por apresentar filídios longos, fortemente bordeados por células longas, costa terminando pouco abaixo do ápice.

Ocorre nos Estados do Acre, Paraíba, Pernambuco, Rio de Janeiro e Roraima; Bahia (Bastos \& Yano 1993). É a primeira referência para o Estado do Paraná.

Fissidens zollingeri Mont., Annls Sci. Nat. Bot., Paris 3(4): 114. 1845.

Tipo: Java (PC).

Ilustração: Yano et al. (1987).

Gametófitos pequenos, simples. Filídios lanceolados ou linear-lanceolados; ápice pontiagudo, levemente acuminado; margem inteira; costa forte, terminando no ápice ou levemente excurrente; células irregularmente hexagonais, margem conspícua, 1-2(-3) fileiras muito longas, estreitas; células da lâmina vaginante distintamente mais largas, principalmente perto da base e da costa. Cápsula ovalada.

Material examinado: no solo úmido junto de árvore, 17/III/1982, Yano 4010p.p. (SP 171857).

Comentários: cresce sobre húmus, solo argiloso, ocasionalmente em madeira podre sob sol ou na sombra.

A espécie apresenta células da lâmina vaginante distintamente mais largas; costa terminando no ápice ou levemente excurrente.

Ocorre nos Estados do Amazonas, Bahia, Goiás, Espírito Santo, Pernambuco (Arquipélago de Fernando de Noronha), Minas Gerais, Maranhão, Mato Grosso do Sul, Pará, Paraíba, Paraná, Pernambuco, Rio de Janeiro, Rondônia, Santa Catarina, São Paulo e Tocantins; Piauí (Castro 1997).

Helicophyllaceae

Helicophyllum torquatum (Hook.) Brid., Univ. 2: 771.1827.

Basiônimo: Anictangium torquatum Hook., Musci Exot. 1: 41. 1818.

Tipo: América do Norte. Ilustração: Yano (1979).

Gametófitos médios, $4-5 \mathrm{~cm}$ compr., verde-amarelados; filídios 1,5-2,0mm compr. ligulados, margem inteira, plana, costa única, terminando perto do ápice, células arredondado-hexagonais, 1-2 papilas ou lisas, 10um diâm. Cápsula gimnóstoma 0,7-1,2 mm alt., reta, cilíndrica, imersa nos filídios periqueciais.

Material examinado: sobre tronco de árvore viva, 17/III/1982, Yano 3979, 4000 ( SP 171836, SP 171850); idem, sobre pedras formando tapete, 18/III/1982, Yano 4040 (SP171874); idem, no paredão que forma as lagoas, 21/III/1982, Yano 4083 (SP 171902).

Comentários: geralmente cresce sobre paredões rochosos ou troncos de árvore; caracteriza-se por possuir filídios de 1,5 a $2,0 \mathrm{~mm}$ compr.; células de $10 \mu \mathrm{m}$ diâm. e ramos de $4,5 \mathrm{~cm}$ compr.

Ocorre nos Estados do Amazonas, Alagoas, Bahia, Ceará, Espírito Santo, Distrito Federal, Goiás, Minas Gerais, Pará, Paraíba, Paraná, Pernambuco, Rio de Janeiro, Santa Catarina e São Paulo. 


\section{Hypnaceae}

Isopterygium tenerifolium Mitt., J. Linn. Soc. Bot. 12: 499. 1869.

Tipo: Brasil, Rio Amazonas, Óbidos, Spruce 1060.

Ilustrações: Sharp et al. (1994).

Gametófitos pequenos, verde-amarelados, ramos subpinados; filídios complandos, 0,7$1,0 \mathrm{~mm}$ compr., oblongo-lanceolados, gradualmente acuminados; margem inteira a serrulada; poucas células alares na base. Seta marromalaranjada, 8-20mm compr., cápsula horizontal a pêndula, ovóide, cilíndrica.

Material examinado: no solo úmido, sombrio perto das lagoas, 21/1II/1982, Yano 4081 (SP 171901)

Comentários: encontrada sobre diferentes tipos de substrato; caracteriza-se pela cor verde-amarelada, filídio oblongo-lanceolado com poucas células alares na base.

Ocorre nos Estados do Amazonas, Bahia, Ceará, Minas Gerais, Pará, Rio de Janeiro, Santa Catarina e São Paulo. É a primeira referência para o Estado do Paraná.

Isopterygium tenerum (Sw.) Mitt., J. Linn. Soc. Bot. 12: 499. 1869.

Basiônimo: Hypnum tenerum Sw., Flora Ind. Occid. 3: 1817. 1806.

Tipo: Jamaica.

Ilustração: Hirai et al. (1998).

Gametófitos pequenos, delicados, esbranquiçados a verde-amarelados. Filídios geralmente sobrepostos, ereto-expandidos, complanados, filídios laterais levemente assimétricos, oblongo-lanceolados, gradualmente acuminados, inteiros a serreados no ápice; células basais levemente alargadas, curtamente oblongas. Seta 8$20 \mathrm{~mm}$ compr.; cápsula horizontal a pendulosa, curvada, ovóide-cilíndrica; opérculo pontiagudo.

Material examinado: sobre tronco perto do rio, 17/III/1982, Yano 4006p.p. (SP 171856).

Comentários: cresce sobre troncos de ár- vores, nos solos principalmente arenosos, em lugares secos, às vezes em lugares encharcados.

A espécie apresenta gametófitos delicados, esbranquiçados a verde-amarelados; filídios levemente assimétricos, oblongo-lanceolados e gradualmente acuminados.

Ocorre nos Estados do Acre, Amazonas, Bahia, Espírito Santo, Goiás, Mato Grosso, Minas Gerais, Pará, Paraná, Paraíba, Pernambuco, Rio Grande do Sul, Rio de Janeiro, Roraima, Santa Catarina e São Paulo.

Leskeaceae

Herpetineuron toccoae (Sull. \& Lesq.) Card., Beih. Bot. Centralbl.19(2): 127. 1905.

Basiônimo: Anomodon toccoae Sull. \& Lesq., Musci Bor. Amer. 52. 1856.

Tipo: América do Norte, Geórgia, Toccoa Fall. Ilustrações: Sharp et al. (1994); Oliveira e Silva (1998).

Gametófitos esparsadamente ramificados; filídios ereto-expandidos, ovalado-lanceolados, agudos, côncavos; margem distinta, serrulada, costa forte, flexuosa, células subquadradas, lisas. Seta $10-15 \mathrm{~mm}$ compr. Cápsulas 2-3mm compr.

Material examinado: no solo úmido da mata, 17/III/1982, Yano 3993(SP 171846); idem, sobre pedras expostas ao sol, 18/III/1982, Yano 4045 (SP 171877); idem, sobre pedra exposta, 19/III/1982, Yano 4052 (SP 171884); idem, no solo úmido perto da mata, 18/III/1982, Yano 4055 (SP 171886).

Comentários: encontrada sobre solo ou sobre tronco; caracteriza-se pelo filídio ovaladolanceolado e agudo, margem irregularmente serrulada e a costa flexuosa perto do ápice.

Ocorre nos Estados do Mato Grosso, Paraná, Rio de Janeiro e Santa Catarina.

Leucobryaceae

Leucobryum sordidum Aongstr., Oefv. K. VetenskAkad. Foerh. 33(4): 7. 1876. 
Tipo: Brasil.

Ilutrações: Yano (1992a).

Gametófitos pequenos, verde-esbranquiçados; filídios lanceolados, subtubulosos, $5,8 \mathrm{~mm}$ compr., ápice tubuloso, agudo, células do ápice subquadráticas; secção transversal da costa no ápice, região mediana e base central 2(l e 1$)$, base marginal 4(2 e 2) camadas de leucócitos. Esporófito não visto.

Material examinado: sobre tronco podre na mata, 19/III/1982, Yano 4027 (SP 171867)

Comentários: geralmente cresce na base do tronco, rochas ou solo; caracteriza-se pelo aspecto sujo.

Ocorre nos Estados da Bahia, Ceará, Espírito Santo, Minas Gerais, Mato Grosso, Paraná, Rio Grande do Sul, Rio de Janeiro, Santa Catarina e São Paulo.

Octoblepharum albidum Hedw., Spec. Musc. Frond. 50. 1801.

Tipo: Jamaica, Swartz $s / n$ (G-1368).

Ilustração: Yano (1992a).

Gametófitos muito variáveis, 5-15(-20)mm alt., verde-pálidos a esbranquiçados, iridescentes quando secos. Filídios patentes, pouco recurvados, algumas vezes purpúreos na base, não frágeis, 5-8(-10)mm de compr., 0,6-0,7 $\mathrm{mm}$ de larg., ápice acuminado raramente agudo, pouco denteado. Vista superficial do filídio: células do ápice retangulares, $40-45 \times 25-30 \mu \mathrm{m}$, da região mediana, retangulares, $50-55 \times 27-30 \mu \mathrm{m}$, da base retangulares 60-65 x 30-35 $\mu \mathrm{m}$. Secção transversal da costa: ápice $4(2$ e 2$)$, região mediana 7-8(3-4 e 4), base 5-7(2 e 3-4(-5) camadas de leucocistos. Lâminas (aletas) ovaladas a oblongas com 11 e 12 fileiras de leucocistos longo-retangulares, $150-160 \times 25-28 \mu \mathrm{m}$, geralmente se estendendo até o ápice, do filídio. Esporófitos sempre presentes, muito abundantes. Seta castanho-clara, 2-6(-7)mm compr. Cápsula ovóide, 1,0-1,5(-2,0) mm compr. Células da parede da cápsula na base retangulares 40-45 x 18-20 $\mu \mathrm{m}$, com estômatos. Opérculo rostrado. Peristômio com 8 dentes triangulares, irregulares, às vezes perfurados próximo a base, $150-160 \mu \mathrm{m}$ compr. Caliptra cuculada, inteira na base. Esporos globosos, lisos, 20-22 $\mu \mathrm{m}$ diâm.

Material examinado: sobre tronco podre perto do rio, 17/III/1982, Yano 4006p.p. (SP 171856).

Comentários: cresce geralmente na base do tronco e no solo em densos tapetes, podendo ainda ser encontrados em diferentes substratos.

A espécie apresenta os filídios planos, ápice agudo e ao redor pequenos dentículos.

Ocorre em todos os estados brasileiros, inclusive no Arquipélago Fernando de Noronha (PE).

\section{Leucodontaceae}

Pseudocryphaea domingensis (Spreng.) Buck, Bryologist 83: 455. 1980.

Basiônimo: Neckera domingensis Spreng., Syst. Veg. Fl. Peruv. Chil. 4(1): 185. 1827.

Tipo: Espanha.

Ilustrações: Yano et al. (1987, como $P$. flagellifera).

Gametófitos secundários dendróides, 50$60 \mathrm{~mm}$ compr., ramos terciários alongados, com ramos flagelíferos. Filídios imbricados quando secos, ovalados, breve-acuminados; margem plana, serrilhada apicalmente; costa delgada, percurrente; células linearromboidais, fracamente papilosas sobre o dorso superior, arredondado, sinuoso e incrassado no ângulo basal, 10-12 fileiras de células. Esporófitos não observados.

Material examinado: sobre tronco de árvores, em tufos, 17/III/1982, Yano 3978 (SP 171835); idem, sobre tronco de árvores vivas, 17/III/1982, Yano 4004 (SP 171854); idem, ilha perto do salto 17 , sobre tronco de árvore junto das pedras 18/III/1982, Yano 4043 (SP 171875).

Comentários: encontrada sobre tronco de árvore, em mata aberta. Caracteriza-se pela presença de ramos flageliformes no ápice, base do filídio com 10-12 fileiras de células 
alares diferenciadas.

Ocorre nos Estados do Amazonas, Alagoas, Bahia, Espírito Santo, Mato Grosso, Minas Gerais, Pará, Paraná, Pernambuco, Rio de Janeiro, Rondônia, Rio Grande do Sul e São Paulo.

\section{Meteoriaceae}

Papillaria deppei C. Muell. ex Jaeg., Ber. St. Gall. Naturw. Ges. 1875-76: 264. 1877.

Basiônimo: Neckera deppei Hornsch. ex C. Muell., Syn. Musc. 2: 136. 1848.

Tipo: México, Deppe \& Schiede s/n. Ilustrações: Hirai et al. (1998).

Gametófitos moderadamente robustos, verde-claros a amarelos; filídios 1,6-2,8mm compr., plicados, lanceolados, triangularlanceolados, base auriculada, gradualmente longo-acuminados, freqüentemente terminando em ápice muito alongado, células apicais lineares, 2-5 papilas, células medianas lineares 2-6 papilas. Seta maior que $6 \mathrm{~mm}$ compr.; cápsula emergente.

Material examinado: sobre tronco de árvore viva, 17/III/1982, Yano 3985 (SP 171839).

Comentários: geralmente cresce sobre tronco e ocasionalmente sobre rochas; caracteriza-se pelo longo ápice do filídio, terminando em um pêlo.

Ocorre nos Estados de Bahia, Paraná, Pernambuco, Rio de Janeiro e São Paulo.

Papillaria nigrescens (Hedw.) Jaeg., Ber. St. Gall. Naturw. Ges. 1875-76: 265. 1877.

Basiônimo: Hypnum nigrescens Hedw., Spec. Musc. Frond. 250. 1801.

Tipo: Jamaica.

Ilustrações: Hirai et al. (1998).

Gametófitos robustos, verde-claros a verde-escuros; filídios lanceolado-acuminados, 1,11,6mm compr., base auriculada, costa única; células romboidais a lineares, 4-7 papilas, células medianas fusiformes a lineares com 3-6 papilas, células basais quadráticas a oblongas, células auriculadas rômbicas a fusiformes. Seta maior que $7 \mathrm{~mm}$ compr.; cápsula emersa.

Material examinado: sobre tronco de árvore viva, 17/III/1982, Yano 3999 (SP 171849); idem, em ilhas, sobre raízes no solo úmido, 20/III/1982, Yano 4057 (SP 171888).

Comentários: cresce sobre tronco de árvores, mas às vezes sobre rochas ou solo; caracteriza-se pelos filídios às vezes quase pretos, lanceolado-acuminados com base auriculada, costa única e células pluripapilosas.

Ocorre nos Estados da Bahia, Espírito Santo, Minas Gerais, Paraná, Pernambuco, Rio de Janeiro, Rio Grande do Sul, Santa Catarina, e São Paulo.

Zelometeorium patulum (Hedw.) Manuel, J. Hattori Bot. Lab. 43: 118. 1977.

Basiônimo: Hypnum patulum Hedw., Spec. Musc. Frond. 279. 1801.

Tipo: Jamaica.

Ilustrações: Manuel (1977).

Gametófitos pendentes, nunca menores que $20 \mathrm{~cm}$ compr., filídios do ramo principal contorcidos, ovalado-lanceolados, longo-acuminados; ápice formado pelo prolongamento da costa; margem plana; células lineares a linearfusiformes; filídios dos ramos secundários esquarrosos a esquarroso-retorcidos, margens planas a finamente serruladas. Caliptra 0,6$0,9 \mathrm{~mm}$ compr.

Material examinado: sobre tronco de árvore viva, 17/III/1982, Yano 4005 (SP 171855); idem, área militar, sobre casca de árvore, 20/III/1982, Yano 4067 (SP 171892).

Comentários: sempre crescendo sobre galhos de forma pendulosa, caracteriza-se pelos filídios com ápice terminando com o prolongamento da costa e pelo tamanho do ramo penduloso.

Ocorre nos Estados do Acre, Amazonas, Amapá, Alagoas, Espírito Santo, Goiás, Mato Grosso, Minas Gerais, Pará, Paraná, Rio de 
Janeiro, Rio Grande do Sul, Roraima, Santa Catarina e São Paulo.

Zelometeorium recurvifolium (Hornsch. in Mart.) Manuel, J. Hattori Bot. Lab. 43: 121. 1977.

Basiônimo: Pilotrichum recurvifolium Hornsch. in Martius, Flora bras. 1(2): 58. 1840.

Tipo: Brasil, Rio de Janeiro.

Ilustrações: Hirai et al. (1998).

Gametófitos com ramos pendentes nunca menores que $30 \mathrm{~cm}$ compr.; filídios contorcidos, ovalados a finamente-ovalados, gradualmente ou abruptamente contraídos no ápice, margem plana, finamente serrulada; células medianas linear-fusiformes. Caliptra 0,8-1,25mm compr.

Material examinado: sobre tronco de árvore, 17/III/1982, Yano 4015p.p. (SP 171860); idem, sobre tronco de árvore viva, 17/III/ 1982, Yano 4017 (SP 171862); idem, no solo e galhos de pequenos arbustos, 21/III/1982, Yano 4080 (SP 171900).

Comentários: cresce sobre galhos de forma pendente; caracteriza-se pelos filídios ovalados e pelo tamanho dos ramos pendentes.

Ocorre nos Estados de Alagoas, Amazonas, Espírito Santo, Goiás, Mato Grosso, Minas Gerais, Paraná, Rio Grande do Sul, Rio de Janeiro, Santa Catarina e São Paulo; Roraima (Yano, 1992b).

Myriniaceae

Helicodontium capillare (Hedw.) Jaeg., Adumb. 2: 291. 1875-76.

Basiônimo: Leskea capillare Hedw., Spec. Musc. Frond. 221. 1801.

Tipo: Jamaica.

Ilustração: Hirai et al. (1998).

Gametófitos verde-escuros quando secos, verde-claros quando úmidos, $3-4 \mathrm{~m}$ compr. Filídios espiralados, eretos, ovalados a oblongo-ovalado-lanceolados, $0,35-0,60 \times 0,10$ -
$0,24 \mathrm{~mm}$; costa forte, 4 fileiras de células estreitas e alongadas, atingindo $1 / 3$ superior do filídio, ápice agudo a curto-acuminado; margem inteira, metade superior do filídio com pequenos dentes formados pela projeção das células marginais; células superiores romboidais a longo-hexagonais, 12,5-20,0 $\mathrm{x}$ $5,0-10,0 \mu \mathrm{m}$; células basais quadráticas, $10,0-$ $12,5 \times 7,5-12,5 \mu \mathrm{m}$. Cápsula ereta a ligeiramente inclinada, cilíndrica, $1,5-2,0 \mathrm{~mm}$ compr., constricta abaixo da boca; opérculo longo-rostrado; seta longa, castanhoavermelhada, lisa, 6-7 mm compr.

Material examinado: sobre húmus em pedra, 17/III/1982, Yano 4001 (SP 171851); idem, sobre tronco de árvore viva na mata, 17/III/1982, Yano 4011 (SP 171858); idem, sobre casca de árvore viva, 17/III/1982, Yano 4029 (SP 171869).

Comentários: cresce sobre grande variedade de substratos, mas de preferência na base dos troncos, sempre fértil.

A espécie se caracteriza pelo gametófito diminuto, filídios ovalados apresentando na região basal um grupo de células quadráticas bastante evidentes.

Ocorre nos Estados do Acre, Bahia, Espírito Santo, Paraná, Rio de Janeiro, Rio Grande do Sul, Santa Catarina e São Paulo.

\section{Neckeraceae}

Neckeropsis disticha (Hedw.) Kindb., Canad. Rec. Sc. 6: 21. 1894.

Basiônimo: Neckera disticha Hedw., Spec. Musc. Frond. 201. 1801.

Tipo: Jamaica.

Ilustrações: Oliveira e Silva (1998).

Gametófitos verde-opacos ou às vezes amarelados; filídio $1,0-1,5 \mathrm{~mm}$ compr., fortemente complanado, enrugado quando seco, largamente oblongo, truncado ou arredondado no ápice; margem \pm serrulada no ápice, quase lisa na base; costa até $3 / 4$ do filídio ou mais; células espessadas, retangulares ou romboidais, gradualmen- 
te passando a oblongo-romboidal. Esporófito séssil, cápsula 1,0-1,5mm compr., marrom ou marrom-amarelada.

Material examinado: sobre tronco de árvore, 17/III/1982, Yano 4015p.p. (SP 171860); idem, sobre tronco de árvore viva, 17/III/ 1982, Yano 4021 (SP 171864); idem, área militar, na base de pequenos arbustos, 20/III/ 1982, Yano 4068 (SP 171893).

Comentários: encontrada sobre tronco ou sobre rocha, caracteriza-se pelo aspecto amassado quando seco, filídio com ápice truncado.

Ocorre nos Estados do Acre, Amazonas, Bahia, Espírito Santo, Goiás, Mato Grosso, Pa-raná, Pernambuco, Rio de Janeiro, Rio Grande do Sul, Roraima, Santa Catarina e São Paulo.

Neckeropsis undulata (Hedw.) Reichdt., Reise Oester. Freg. Novara Bot. 1: 181. 1870.

Basiônimo: Neckera undulata Hedw., Spec. Musc. Frond. 201. 1801.

Tipo: Jamaica.

Ilustrações: Oliveira e Silva (1998).

Gametófitos verde-claros ou amarelados; filídio $1,5-2,0 \mathrm{~mm}$ compr., ondulado, quando seco, oblongo, ápice truncado ou arredondado-truncado; margem serrulada no ápice $\mathrm{e}$ pouco distinto na base: costa terminando $3 / 4$ do filídio ou mais, células retangulares a rômbicas. Seta curta, cápsula 1,0-1,8mm compr., marrom-amarelada.

Material examinado: sobre tronco de árvore viva, 17/III/1982, Yano 4018 (SP 171863); idem, área militar, sobre tronco de árvore, 20/III/1982, Yano 4077 (SP 171898); idem, sobre tronco de árvore viva, 20/III/ 1982, Yano 4059p.p. (SP 171890).

Comentários: cresce sobre tronco ou rocha; caracteriza-se pelo aspecto ondulado quando seco e ápice truncado.

Ocorre nos Estados do Acre, Alagoas, Amazonas, Amapá, Bahia, Distrito Federal, Goiás, Maranhão, Minas Gerais, Mato Gros- so, Pará, Paraná, Pernambuco, Rio de Janeiro, Rio Grande do Sul, Rondônia, Roraima, Santa Catarina e São Paulo.

Orthotrichaceae

Groutiella apiculata (Hook.) Crum \& Steere, Bryologist 53: 146. 1950.

Basiônimo: Orthotrichum apiculatum Hook., Musci Exot. 45. 1818.

Tipo: Saint Vicent.

Ilustrações: Sharp et al. (1994).

Gametófitos verde-escuros a amarronzados; filídios linear-lanceolados; ápice obtuso, mucronado, às vezes acuminado com mucro bem diferenciado, margem inteira, finamente ondulada, costa forte, excurrente, ápice mucronado; células superiores do filídio irregularmente arredondadas, lisas, exceto na extremidade basal, onde são finamente piloso-tuberculadas. Seta maior que $5 \mathrm{~mm}$ compr., cápsula ovalado-piriforme, $1,5 \mathrm{~mm}$ compr.

Material examinado: sobre galhos de árvore viva, 17/III/1982, Yano 3986 (SP 171840).

Comentários: cresce sobre tronco; caracteriza-se pelo ápice mucronado e apiculado.

Ocorre nos Estados de Mato Grosso do Sul, Pará, Pernambuco, Rio de Janeiro e São Paulo. É a primeira referência para o Estado do Paraná.

Macromitrium richardii Schwaegr., Spec. Musc. Frond. Suppl. 2(2): 70. 1826.

Tipo: Guiana.

Ilustração: Oliveira e Silva (1998).

Gametófitos delicados, verde-amarelados. Caulídios eretos, $6 \mathrm{~mm}$ compr. Filídios enrolados quando secos, $1,4 \times 0,5 \mathrm{~mm}$, lanceolados, quilhados; ápice obtuso; margem crenulada; costa forte; células superiores hexagonal-arredondadas, papilosas (mais de uma papila) 9,6 $\mathrm{x}$ 7,2 um, parede espessa; células basais lisas, alongadas $24,0-9,6 \times 4,8 \mu \mathrm{m}$, paredes espessa- 
das, sinuosas, espessamentos intercelulares. Seta lisa $10 \mathrm{~mm}$ compr., cápsula $1,5 \mathrm{~mm}$ compr. com sulcos longitudinais, quando seca.

Material examinado: sobre tronco de Tiliaceae, 17/III/1982, Yano 3966 (SP 171829).

Comentários: cresce sobre tronco vivo, em decomposição ou sobre pedras de ambientes úmidos ou secos.

A espécie se caracteriza pelo ápice do filídio obtuso, margem crenulada, costa forte e células superiores papilosas e as basais lisas.

Ocorre nos Estados de Amazonas, Espírito Santo, Minas Gerais, Paraná, Rio de Janeiro, Rio Grande do Sul, Santa Catarina e São Paulo; Bahia (Yano \& Bastos 1994/1995).

\section{Pottiaceae}

Erythrophyllastrum andinum (Sull.) Zand., Bull. Buffalo Soc. Nat. Sci. 32: 74. 1993.

Basiônimo: Trichostomum andinum Sull., U. S. Expl. Exp. Wilkes Musci 5.2 1859.

Tipo: Peru, Andes, U.S. Expl. Exp. Wilkes 18381842.

Ilustração: Zander (1993).

Gametófitos verdes a marrom-avermelhados abaixo. Filídios apresso-incurvados, quando secos, largamente espalhados quando úmidos, lanceolados, 2-3mm compr., costa forte, excurrente, margem plana inteira, lâmina superior uniestratosa ou variavelmente, biestratosa até a base, ápice agudo, base mais larga; células da superfície quadráticas, papilosas, geralmente curto-retangulares próximo do ápice, dorsalmente quadráticas e retangulares na base, 10-16 fileiras de células através da costa central ao meio do filídio. Esporófito não observado.

Material examinado: sobre pedra úmida, 17/ III/1982, Yano 3983 (SP 171838).

Comentários: cresce geralmente sobre pedras úmidas. Caracteriza-se por apresentar a base dos filídios larga, formando um ombro e com células retangulares e hialinas como em Calymperes. Em secção transversal uniestratosa no ápice ou biestratosa irregularmente e biestratosa em direção a base, pluripapilosas. Segundo Zander (1993) só ocorre nas regiões andinas.

É a primeira referência para o Brasil.

Tortella humilis (Hedw.) Jenn., Mann. Moss. W. Pennsylv. 96: 13. 1913.

Basiônimo: Barbula humilis Hedw., Spec. Musc. Frond. 116. 1801.

Tipo: ad Lancaster, Pensilvania.

Ilustrações: Hirai et al. (1998).

Gametófitos pequenos, em grandes tufos $\pm 5 \mathrm{~mm}$ compr., verdes ou verde-amarelados; filídios bem crespos quando secos, oblongolanceolados, 2,2-3,5 mm compr., finamente apiculados, côncavos, costa pouco excurrente. Seta amarela 7-18mm compr., cápsula marrom-clara $1,5-3,0 \mathrm{~mm}$ compr.

Material examinado: Ilha perto do salto 17, na base de grandes pedras, 18/III1982, Yano 4046 (SP 171878).

Comentários: cresce sobre troncos, rochas ou solo; caracteriza-se pelo filídio bem crespo quando seco, seta amarela e cápsula marrom-clara.

Ocorre nos Estados da Bahia, Espírito Santo, Minas Gerais, Paraná, Rio Grande do Sul, Rio de Janeiro, Santa Catarina e São Paulo.

\section{Ptychomitriaceae}

Ptychomitrium vaginatum Besch., Mem. Soc. Sc. Nat. Cherbourg 21: 262. 1877.

Tipo: Paraguai, Cerro Hu, M. Balansa 1234.

\section{Fig. 2a-g}

Gametófitos $\pm 1,5 \mathrm{~mm}$ alt., verde-escuros; filídio longo, ligulado, base larga, alargando-se mais formando um ombro e se estreitando rapidamente, apiculado, $\pm 3 \mathrm{~mm}$ compr.; costa crassa, percorrendo a lâmina e sobressaindo em apículos; células da parte larga da lâmina são hialinas, basais retangulares e apicais arredon- 


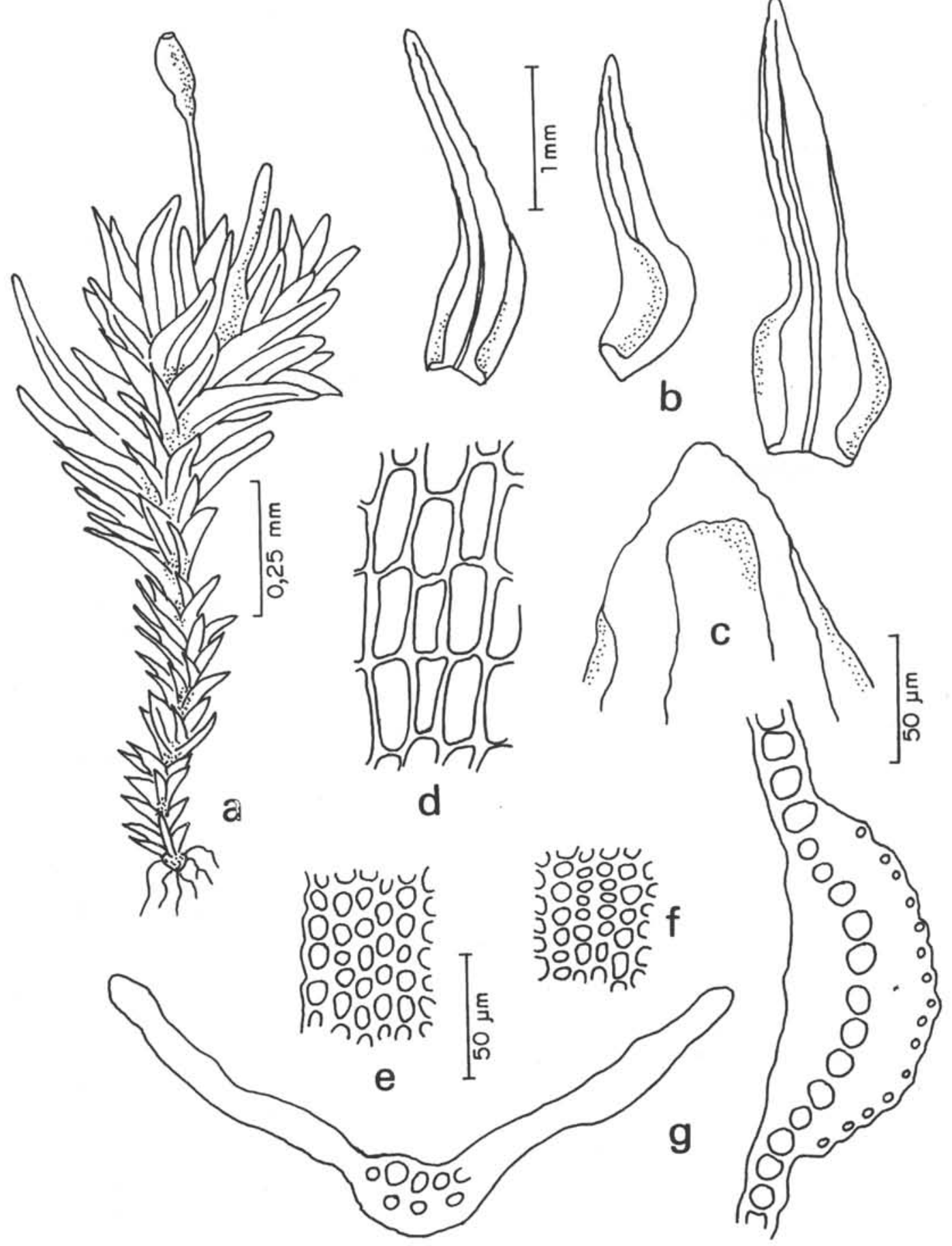

Figuras 2a-g. Ptychomitrium vaginatum Besch. a. aspecto geral do gametófito; b: filídios; c. detalhe apical do filídio; d. células da base do filídio; e. células da margem do filídio; f. células superiores do filídio; g. secção transversal do filídio, costa com estereídio (Yano 4047). 
dado-quadradas. Seta $0,4-0,5 \mathrm{~mm}$ compr., cápsula oblonga, $1,2 \mathrm{~mm}$ compr.

Material examinado: sobre sobre grandes pedras ao sol, 18/III/1982, Yano 4047 (SP 171879).

Comentários: cresce sobre rochas ou substratos expostos ao sol e junto a córregos; caracteriza-se pela base larga do filídio, tornando-se mais larga formando o ombro e depois se estreita bruscamente ou não.

Ocorre nos Estados do Paraná, Rio de Janeiro, Rio Grande do Sul, Santa Catarina e São Paulo.

\section{Racopilaceae}

Racopilum tomentosum (Hedw.) Brid., Bryol. Univ. 2: 719. 1827.

Basiônimo: Hypnum tomentosum Hedw., Spec. Musc. Frond. 240. 1801.

Tipo: Hispaniola $(\mathrm{G})$.

Ilustrações: Hirai et al. (1998).

Gametófitos medianos, verde-escuros ou amarelo-amarronzados; filídios dimórficos, filídios laterais ondulados em torno do caulídio quando secos, complanados quando úmidos, oblongos, estreitando-se abruptamente e o ápice longo; filídios dorsais oblíquos, triangulares ou lanceolados, afinando gradualmente até o ápice bem conspícuo; células do ápice pequenas, verdes, irregularmente subquadradas, células basais subquadráticas ou quase oblongas; seta $10-30 \mathrm{~mm}$ compr., tornando-se avermelhada com a idade, lisa, 2,5-4,0mm compr. inclinada e cilíndrica.

Material examinado: Salto 14, sobre tronco podre, 17/III/1982, Yano 3971 (SP 171831); idem, no húmus da mata úmida, 17/III/1982, Yano 3975 (SP 171833); idem, no solo, úmido, borrifo de água da cachoeira, 17/III/1982, Yano 3991 (SP 171844); idem, sobre tronco de árvore viva, 17/III/1982, Yano 4002 (SP 171852); idem, sobre tronco podre na mata, 17/III/1982, Yano 4016(SP 171861); idem, ilha perto do salto $17,18 / \mathrm{III} / 1982$, Yano 4049 (SP 171881).
Comentários: pode ser encontrada sobre solo ou sobre rocha e tronco podre; caracterizase pela fileira de filídios dorsais de formato triangular ou lanceolado com costa excurrente.

Ocorre nos Estados do Amazonas, Bahia, Ceará, Distrito Federal, Espírito Santo, Goiás, Mato Grosso, Mato Grosso do Sul, Minas Gerais, Pará, Paraná, Pernambuco, Rio Grande do Sul, Rio de Janeiro, Rondônia, Santa Catarina e São Paulo.

\section{Sematophyllaceae}

Sematophyllum caespitosum (Hedw.) Mitt., J. Linn. Soc. Bot. 12: 479. 1869.

Basiônimo: Leskea caespitosa Hedw., Spec. Musc. Frond. 233. 1801.

Tipo: Ilha Hispaniola.

Ilustrações: Hirai et al. (1998).

Gametófitos médios, verde-opacos; filídios crenulados, 0,8-1,1mm compr., oblongo-lanceolados a oblongo-apiculados, acuminados; células do ápice com espessamento da parede, tornando-se mais arredondadas do que as medianas; células alares infladas 3-6. Seta 5-10mm compr.; cápsula subereta e simétrica.

Material examinado: área militar, na base de pequenos arbustos, 20/III/1982, Yano 4069 (SP 171894); idem, sobre tronco de árvore (base), 20/III/1982, Yano 4076 (SP 171897).

Comentários: geralmente cresce sobre tronco de árvore; caracteriza-se pelas células mais arredondadas que as medianas, espessadas no ápice e células alares em número de 3-6.

Ocorre nos Estados do Amazonas, Amapá, Ceará, Espírito Santo, Goiás, Mato Grosso, Minas Gerais, Pará, Paraná, Paraíba, Pernambuco, Rio Grande do Sul, Rio de Janeiro, Roraima, Santa Catarina e São Paulo; Bahia (Bastos \& Yano 1993).

Stereophyllaceae

Eulacophyllum culteliforme (Sull.) Buck \& 
Ireland, Nova Hedwigia 41: 108. 1985. Basiônimo: Hypnum cultelliforme Sull., Proc. Amer. Acad. Arts 5: 289. 1861.

Tipo: Cuba.

Ilustrações: Buck \& Ireland (1985).

Gametófitos pequenos, verde-amarelados; filídio oblongo-lanceolado a oblongo-ovalado, agudo a obtuso; margem plana, densamente serrulada; costa única até o meio do filídio; células medianas alongadas, células da base retangulares, irregularmente dispostas. Seta alaranjada a amarronzada, caliptra cuculada.

Material examinado: sobre tronco de árvore viva, 17/III/1982, Yano 3976 (SP 171834).

Comentários: encontrada geralmente sobre tronco; caracteriza-se pelas células retangulares irregularmente dispostas na base do filídio, margem densamente serrulada.

Ocorre nos Estados do Espírito Santo, Minas Gerais, Mato Grosso do Sul, Mato Grosso, Paraná, Paraíba, Pernambuco, Rio de Janeiro, São Paulo e Sergipe.

Stereophyllum radiculosum (Hook.) Mitt., J. Linn. Soc. Bot. 12: 542. 1869.

Basiônimo: Hookeria radiculosa Hook., Musci Exot. 1: 51. 1818.

Tipo: México.

Ilustrações: Sharp et al. (1994).

Gametófitos verdes a amarelos; filídios complanados, oblongo-ovalados a oblongoligulados, serrulados em direção ao ápice; costa $2 / 3$ do filídio, células rômbicas a fusiformes perto do ápice, unipapilosas perto do meio do filídio. Seta 8-11 mm compr., cápsula subereta a inclinada ou horizontal 1,0-1,3mm compr.

Material examinado: sobre tronco de árvore vivo, 17/III/1982, Yano 3980, 3996pp. (SP 171837, SP 171847); idem, sobre tronco de árvore podre, 17/III/1982, Yano 3997(SP 171848); idem, 19/III/1982, Yano 4053 (SP 171885); idem, em Ilha no Parque Nacional de Sete Quedas, sobre tronco de árvore, 20/III/1982, Yano 4058(SP 171889); idem, área militar, sobre tron- co de árvore viva, 20/III/1982, Yano 4079 (SP 171899).

Comentários: geralmente cresce sobre tronco de árvore; caracteriza-se pelas células rômbicas perto do ápice e papilas no meio do filídio.

Ocorre nos Estados da Bahia, Espírito Santo, Minas Gerais, Mato Grosso do Sul, Pará, Paraná, Rio de Janeiro, Rio Grande do Sul e São Paulo.

Thuidiaceae

Thuidium tomentosum Schimp. ex Besch., Mém. Soc. Sci. Nat. Cherbourg 16: 237. 1872. Tipo: México, Orizaba (NY).

Ilustrações: Gier (1980); Oliveira e Silva (1998).

Gametófitos geralmente robustos, verdeamarelados, às vezes amarronzados, bi- a tripinados; filídios ovalado-triangulares, base subcordada, sulcada, acuminada, 1,0-1,5mm compr., costa percurrente; margem irregularmente recurvada, células pequenas, oblongas, papilosas. Filídios periqueciais com cílios. Seta 20-30mm compr., avermelhada, lisa; cápsula arqueada, cilíndrica $\pm 3,5 \mathrm{~mm}$ compr.

Material examinado: sobre pedra perto das lagoas, 21/III/1982, Yano 4084 (SP 171903).

Comentários: cresce sobre qualquer substrato. Caracteriza-se pela presença de cílios nos filídios periqueciais.

Ocorre nos Estados do Espírito Santo e Rio de Janeiro. É a primeira referência para o Paraná.

Hepatophyta

Frullaniaceae

Frullania ericoides (Nees) Nees in Gott., Lindenb. \& Nees, Syn. Hepat.: 417. 1845.

Basiônimo: Jungermannia ericoides Nees in Martius, Flora bras. enum. plant. 1(1): 346. 1833.

Tipo: Brasil, Minas Gerais in Morro de Villa Rica (Ouro Preto).

Ilustrações: Vanden Berghen (1976). 
Gametófitos verdes ou marrom-avermelhados, irregularmente pinados; filídios imbricados, fortemente esquarrosos; lobo ovalado, arredondado no ápice, margem dorsal arredondada, arqueando-se ao longo da margem do caulídio; células da parede com trigônios triangulares a nodulosos; lóbulo sacado, galeado; anfigastro imbricado, plano, suborbicular, reniforme ou ovalado. Perianto emergente, obovóide a elíptico, 3 quilhas (2 laterais e 1 ventral) estreito e elevado.

Material examinado: sobre tronco de Tiliaceae, 17/III/1982, Yano 3965(SP 174188); idem, sobre tronco de árvore viva, 17/III/1982, Yano 3977(SP 174194); idem, sobre tronco de árvore, 17/III/1982, Yano 3984 (SP 174197); idem, sobre tronco podre na mata, 17/III/1982, Yano 3998 (SP 174201); idem, sobre pedra exposta ao sol, 18/III/1982, Yano 4042 (SP 174219); idem, área militar, sobre tronco de árvore viva, 20/III/1982, Yano 4061 4063, 4074 (SP 174224, SP 174226, SP 174232); idem, sobre casca de árvore, 20/III/1982, Yano 4064 (SP 174227); idem, salto 14 do Parque, sobre tronco de árvore viva, 17/III/1982, Yano 3967, 3968 (SP 174189, SP 174190).

Comentários: cresce sobre tronco ou rocha; caracteriza-se pela posição esquarrosa dos filídios.

Ocorre nos Estados da Bahia, Espírito Santo, Goiás, Minas Gerais, Paraíba, Pernambuco, Arquipélago de Fernando de Noronha, Rio de Janeiro, Rio Grande do Sul, São Paulo e Sergipe. É a primeira referência para o Estado do Paraná.

Frullania inflata Gott. in Gott., Lindenb. \& Nees, Syn. Hepat. 424. 1845.

Tipo: Red River, Whastite, Beyrich 167.

\section{Fig. 3a-h}

Gametófitos verdes a verde-olivas, raramente marrons. Filídios aproximados ou pouco imbricados, suborbicular a fortemente ovalado, margem deflexa. Lóbulo largamente expandi- do, pequeno e lanceolado-ligulado a ovalado, ápice águdo, inflado galeado de tamanho moderado, abertura da boca larga. Estilete vestigial 1-2 células na base, 3-5 células no comprimento; células com trigônios moderados, sem espessamentos intermediários. Anfigastro pequeno, ovalado a quadrado-orbicular, bífido, com lobos agudos a subagudos, margem geralmente inteira. Androceu sobre ramo lateral curto, sem filídios normais em forma de botão arredondado e compacto, 2-3(-4) pares de filídios densamente imbricados, brácteas bilobadas, gineceu não observado.

Material examinado: sobre pedra exposta ao sol, 18/III/1982, Yano 404I (SP 174218).

Comentários: cresce sobre pedra exposta ao sol ou casca de árvore. O lóbulo normal é galeado e inflado e a boca largamente aberta ou maioria das vezes forma uma expansão lanceolado-ligulada a ovalada com o ápice agudo; estilete geralmente vestigial 1-2 células na base e 3-5 células no comprimento. O epíteto correto é Frullania inflata Gott. e não $F$ inflata Herzog em 1921 da Bolívia.

Ocorre apenas no Estado da Bahia. É a primeira referência para o Paraná.

Frullania neesï Lindenb. in Gott., Lindenb. \& Nees, Syn. Hepat.: 450: 1845.

Tipo: Brasil, Minas Gerais, Ouro Preto como Vila Rica.

Ilustrações: Lemos-Michel (1980).

Gametófitos escuros, marrom-avermelhados ou vináceos, pequenos; filídios imbricados, subarredondados, ápice obtuso, margens lisas, base dorsal arredondada não se arqueando sobre o caulídio; células da porção apical com paredes espessas e trigônios freqüentes; lóbulos $2 \mathrm{x}$ mais longos do que largos, subparalelos ao caulídio, geralmente com o ápice mais próximo do caulídio do que a base, ocasionalmente laminares ou caniculados; estilete filiforme 3 ou 4 células de comprimento. Anfigastros distanciados, de mesma largura que o caulídio, ovalado-retangulares, margens lisas ou com um ou 


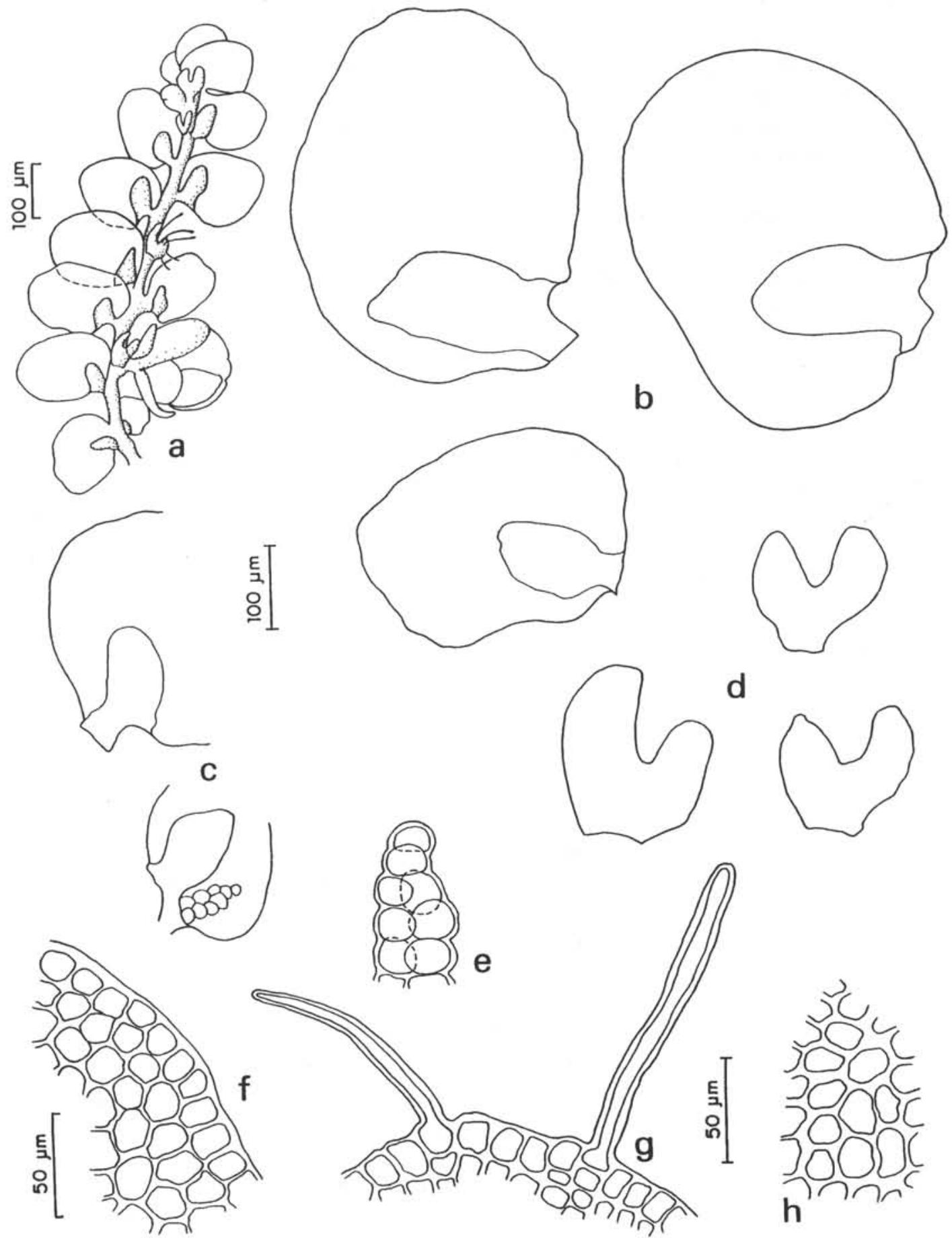

Figuras 3a-h. Frullania inflata Gott. a. aspecto geral do gametófito, vista ventral; b. Filídios com lóbulo; c. lóbulo; d. anfigastros; e. detalhe do estilete; f. células marginais do filídio; g. células marginais com rizóide; h. células centrais, parede espessada (Yano 404I). 
dois dentes, base truncada, bífidos até $1 / 3$ do seu comprimento. Perianto emergente até metade de seu comprimento, obovado, liso, com 3 quilhas (2 laterais e 1 ventral).

Material examinado: área militar, sobre tronco de árvore viva, 20/III/1982, Yano 4065 (SP 174228).

Comentários: cresce sobre troncos e ocasionalmente sobre rochas. Caracteriza-se pela posição do lóbulo com ápice mais próximo do caulídio do que a base.

Ocorre nos Estados do Acre, Amazonas, Ceará, Espírito Santo, Mato Grosso, Minas Gerais, Paraíba, Pernambuco, Rio de Janeiro, Rio Grande do Sul, Roraima, São Paulo e Sergipe; Bahia (Vilas Bôas-Bastos \& Bastos 1998). É a primeira referência para o Paraná.

Frullania riojaneirensis (Raddi) Spruce, Trans. Proc. Bot. Soc. Edinburgh 15: 23. 1884.

Basiônimo: Frullanoides riojaneirensis Raddi, Atti. Soc. Ital. Sci. Modena 19: 37. 1822.

Tipo: Brasil, Rio de Janeiro, Monte Corcovado. Ilustrações: Lemos-Michel (1980).

Gametófitos esverdeados ou amarronzados, 15-50mm compr.; filídio imbricado, subarredondado, levemente côncavo, ápice obtuso, plano, ou levemente recurvo para o lado ventral, margens lisas; células da porção apical subquadrangulares com trigônios, células da porção intermediária irregulares com trigônios conspícuos; lóbulo mais largo do que longo, galeado, inflado na porção superior e rostrado, estilete com 2 a 4 células; anfigastro imbricado, 3 a $4 x$ mais largo que o caulídio, bífido até $1 / 5$ do seu comprimento. Perianto liso, trapezoidal em secção transversal, 4 quilhas (2 laterais e 2 ventrais)

Material examinado: sobre tronco de Tiliaceae, 17/III/1982, Yano 3963 (SP 174186); idem, sobre tronco de árvore viva, 17/III/1982, Yano 3982 (SP 174196).

Comentários: cresce sobre tronco de árvores isoladas. Caracteriza-se pelo lóbulo rostrado e anfigastro finamente bífido (1/5).
Ocorre nos Estados da Bahia, Distrito Federal, Espírito Santo, Goiás, Minas Gerais, Mato Grosso, Pará, Paraíba, Pernambuco, Rio de Janeiro, Rio Grande do Sul e São Paulo. É a primeira referência para o Paraná.

\section{Geocalycaceae}

Lophocolea coadunata (Sw.) Mont., D'Orbigny Voy. Amer. Mer. 7, Bot. 2: 76. 1839.

Basiônimo: Jungermannia coadunata Sw., Flora Ind. Occid. 3: 1850. 1806.

Tipo: Jamaica.

Ilustrações: Fulford (1976).

Gametófitos pequenos a medianos, verdeclaros; filídios de 2,0-2,3mm compr., alternados a subopostos, retangular a ovalados, bífidos até 1/4 ou menos; células superiores do filídio hexagonais, paredes espessas com trigônios evidentes; anfigastros escassos, até $2 / 3$ com 2 a 3 dentes na margem. Perianto 3 quilhado e inúmeros dentes.

Material examinado: sobre tronco podre perto das lagoas, 21/III/1982, Yano 4082 (SP 174234).

Comentários: cresce sobre tronco, rocha ou às vezes epífila. Caracteriza-se pelo filídio bífido até $1 / 4$ do compr. e anfigastro bífido até $2 / 3$ do compr.

Ocorre nos Estados do Amazonas, Goiás, Minas Gerais, Rio de Janeiro, Rio Grande do Sul e São Paulo. É a primeira referência para o Paraná.

Lejeuneaceae

Brachiolejeunea laxifolia (Taylor) Schiffn. in Engler \& Prantl, Nat. Pflanzenfam. 1(3): 128. 1893.

Basiônimo: Phragmicoma laxifolia Taylor, London J. Bot. 6: 431.1847.

Tipo: Equador, Mt. Pichincha (FH-TAYL). Ilustrações: Gradstein (1994).

Gametófitos medianos, verde-olivas quando úmidos e mais escuros quando secos; filídios 
laxos, imbricados, convexos; lóbulo 3-4(-5) dentes, ovalado-falcado; oleocorpos homogêneos, elíptico-fusiformes; anfigastros subimbricados, orbiculares, a base arredondada e levemente decurrente.

Material examinado: epífila, 17/III/1982, Yano 4009 (SP 174204); idem, sobre casca de árvore viva, 17/III/1982, Yano 4012(SP 174205).

Comentários: é epífila, mas às vezes cresce sobre tronco. Caracteriza-se pela presença de 34 dentes no lóbulo e um dente de 1-4 células no caulídio.

Ocorre nos Estados de Minas Gerais, Rio de Janeiro, Rio Grande do Sul e Santa Catarina.

É a primeira referência para o Estado de Paraná.

Brachiolejeunea leiboldiana (Gott. \& Lindenb.) Schiffn., Hedwigia 33: 182. 1894.

Basiônimo: Phragmicoma leiboldiana Gott. \& Lindenb., Syn. Hepat. 296. 1845.

Tipo: México, Leibold $s / n(\mathrm{~W})$.

Ilustrações: Slageren (1985).

Gametófitos $\pm 50 \mathrm{~mm}$ compr., verdeolivas quando úmidos a marrom-escuros quando secos. Caulídio 0,15-0,20mm diâm., em secção transversal 12-20 células epidérmicas, 30-70 células medulares; merófito ventral 4 fileiras de células de largura. Filídios imbricados, esquarrosos quando úmidos, lobo obovado-suborbicular, 1,0$1,4 \times 0,8-1,4 \mathrm{~mm}$, ápice geralmente arredondado, ocasionalmente apiculado. Lóbulo claramente ovalado-subquadrado, ápice fortemente truncado, margem livre plana com apenas $2(-3)$ dentes, anfigastro imbricado, \pm orbicular. Perianto curto, emerso, 1-2 inovações; rosto 2-4 células de compr.

Material examinado: na base do tronco de árvore, 17/III/1983, Yano 4030p.p. (SP 174212).

Comentários: coletada na base dos troncos de árvore viva, na mata úmida geralmente em altitudes de 800 a $2000 \mathrm{~m}$. Caracteriza-se por apresentar lóbulo com somente dois dentes; 1-2 inovações, não aos pares.
Ocorre nos Estados da Bahia, Minas Gerais e São Paulo. É a primeira referência para o Paraná.

Bryopteris fruticulosa Tayl., London J. Bot. 5: 382. 1846.

Tipo: St. Domingo.

Ilustrações: Stotler \& Crandall-Stotler (1974); Lemos-Michel \& Yano (1998).

Gametófitos amarronzados, grandes, regularmente pinados; filídios esquarrosos, imbricados, assimetricamente ovalados, margem inteira, ápice pouco e irregularmente denteado; anfigastros imbricados, ovalados, arredondado a truncado, margens laterais inteiras; lóbulo mediano, inteiro, margem inteira.

Material examinado: sobre tronco de árvore, 19/III/1982, Yano 4054 (SP 174220).

Comentários: cresce tanto sobre rocha como sobre tronco. Caracteriza-se pelo aspecto regularmente pinado e pelo ápice do filídio pouco denteado.

Ocorre nos Estados do Amazonas, Bahia, Distrito Federal, Espírito Santo, Goiás, Mato Grosso, Minas Gerais, Paraná, Pernambuco, Rio de Janeiro, Rio Grande do Sul, Santa Catarina e São Paulo.

Cheilolejeunea adnata (Kunze ex Lehm.) Grolle, J. Bryol. 9: 529. 1977.

Basiônimo: Jungermannia adnata Kunze ex Lehm., Nov. Stirp. Pug. 6: 46. 1834.

Tipo: Cuba.

Ilustrações: Schuster (1980).

Gametófitos claros, medianos; filídios ovalados a subovalados, planos achatados a convexos dorsalmente; ápice bordeado, arredondado a pouco subtruncado; margem fortemente arqueada, curvando-se para o ápice; lóbulo ovóide, muito inflado; presença de filídios caducos iguais aos demais; células com trigônios moderados; 3-4 oleocorpos por célula, grandes, elípticos a fusiformes; anfigastro relativamente pequeno. Perianto ventralmente com uma única fenda obtusa, arredondada na parte mediana. 
Material examinado: sobre húmus na mata, 17/III/1982, Yano 3974 (SP 174193).

Comentários: cresce sobre troncos, às vezes sobre húmus. Caracteriza-se pela presença de filídios caducos.

Ocorre nos Estados do Amazonas, Mato Grosso, Pernambuco e Paraná; Roraima (Santiago 1997).

Cheilolejeunea clausa (Nees \& Mont.) Steph., Hedwigia 29: 80. 1890.

Basiônimo: Lejeunea clausa Nees \& Mont., Ann. Sci. Nat. Bot. sér 2.14: 337. 1840.

Tipo: Guiana Francesa, Mt. Serpent.

Ilustração: Schuster (1980).

Gametófitos verdes a verde-acinzentados, medianos; filídios imbricados, bem arredondados; lóbulo fortemente inflado; anfigastro imbricado, muito largo tanto quanto os filídios; células com grandes trigônios. Perianto obovóide, base cuneiforme, arredondada a arredondado-truncada

Material examinado: Salto 14, sobre tronco podre na mata, 17/III/1982, Yano 3969 (SP $174191)$; idem, sobre tronco vivo, 17/III/ 1982, Yano 4020 (SP 174208).

Comentários: cresce sobre tronco de árvores. Caracteriza-se pelos anfigastros bem largos, arredondados.

Ocorre apenas em Pernambuco. É a primeira referência para o Paraná.

Cheilolejeunea rigidula (Nees ex Mont.) Schust., Castanea 36: 102. 1971.

Basiônimo: Lejeunia rigidula Nees ex Mont., Ann. Sci. Nat. ser. 2, 14: 336. 1840.

Tipo: Guiana Francesa.

Ilustração: Oliveira e Silva (1998).

Gametófitos verde-amarelados, prostrados. Caulídios ramificados, secção transversal, 7 células corticais, 11 medulares menores, paredes espessadas. Filídios distantes a imbricados, eretos. Lobo ovalado 264-265 x 285-286 $\mu \mathrm{m}$; ápice arredondado; margem inteira, sendo a dorsal muito curva. Lóbulos grandes, inflados, tri- angulares $85-86 \times 102-103 \mu \mathrm{m}$. Células marginais retangulares $8-12 \times 6-14 \mu \mathrm{m}$; centrais ovaladas 13-24 x 6-14 $\mu \mathrm{m}$; trigônios triangulares, 1-4 oleocorpos persistentes. Anfigastros distantes, curtamete bífidos, lobos sinus em "V"; inserção do caulídio arqueado, merófito central 2 células de largura. Esporófito não observado.

Material examinado: sobre húmus na base da árvore, 17/III/1982, Yano 4032p.p. (SP 174214).

Comentários: cresce sobre tronco vivo, em decomposição, pedras úmidas e sobre húmus na base do tronco.

A espécie se caracteriza pelos filídios com lobos ovalados; células com oleocorpos persistentes; anfigastros com sinus em "V".

Ocorre no Estado do Acre, Pernambuco, Espírito Santo, Roraima e Rio de Janeiro; Bahia (Vilas Bôas-Bastos \& Bastos 1998). É a primeira referência para o Paraná.

Cololejeunea cardiocarpa (Mont.) Steph., Hedwigia 29: 91. 1890.

Basiônimo: Lejeunea cardiocarpa Mont., Hist. Phys. Polit. Nat. Île de Cuba, Bot. 446-447: 1838. 1842.

Tipo: North America.

Ilustrações: Tixier (1985); Costa \& Yano (1998).

Gametófitos pequenos, verde-claros; filídios oblongo-ovalados, margem hialina limitada ao ápice com \pm 10 células; margem lisa; lóbulo reniforme, às vezes muito reduzido; anfigastros ausentes. Perianto, $0,5 \mathrm{~mm} \times$ $0,35 \mathrm{~mm}$ compr.

Material examinado: área militar, epífilas, 20/III/1982, Yano 4060p.p., 4060ap.p., 4060bp.p. (SP 174221, SP 174222, SP 174223).

Comentários: é geralmente epífila. Caracteriza-se pela presença de células hialinas limitadas ao ápice \pm 10 células.

Ocorre nos Estados do Amazonas, Espírito Santo, Rio de Janeiro, Rondônia e São Paulo; Roraima (Santiago 1997). É a primeira referência para o Paraná. 
Lejeunea flava (Sw.) Nees, Natur. Eur. Leberm. 3:277. 1838.

Basiônimo: Jungermannia flava Sw., Nova Gen. Spec. Plant. Prodr.: 144. 1788.

Tipo: Brasil.

Ilustração: Oliveira e Silva (1998).

Gametófitos pequenos, amarelos a verde-pálidos, prostrados. Caulídios ramificados, secção transversal, 6 células corticais, 10-11 células medulares, 3 ventrais, 7-8 circundando. Filídios distantes a fracamente imbricados, complanados, expandidos. Lobo ovalado a oblongo, $428 \times 321 \mu \mathrm{m}$; margem inteira; ápice obtuso. Lóbulos pequenos, ovalado-triangulares, inflados $77 \times 51 \mu \mathrm{m}$. Células centrais ovaladas $20,0-20,6 \times 17,0-17,2 \mu \mathrm{m}$; marginais $13,0-14,0 \times 10,0-10,3 \mu \mathrm{m}$, trigônios triangulares pequenos. Anfigastros grandes, mais largos que longos, contíguos a imbricados, 235-236 x 228-229 $\mu$ m; merófito ventral 2 células larg.; ápice do lóbulo terminado por uma célula. Esporófito não observado.

Material examinado: sobre tronco podre na mata, 17/III/1982, Yano 4008 (SP 174203).

Comentários: cresce em qualquer substrato, mas preferencialmente na base do tronco de árvore e arbusto.

A espécie apresenta os anfigastros contíguos a imbricados e são mais largos do que longos, os trigônios são pequenos a medianos.

Ocorre nos Estados do Acre, Amazonas, Espírito Santo, Paraná, Paraíba, Pernambuco, Minas Gerais, Rio de Janeiro, Roraima e São Paulo.

Lejeunea glaucescens Gott. in Gott., Lindenb. \& Nees, Syn. Hepat.: 378. 1845.

Tipo: Brasil.

Ilustrações: Schuster (1980); Costa \& Yano (1998).

Gametófitos simples ou em tufos, verdeclaros, opacos; ramo principal geralmente pequeno; fracamente imbricado, estendendo-se a oblíquos, convexos, margem finamente crenulada; lobo virtualmente ovalado a triangular-ovalado, às vezes dividindo-se em dois, polimórficos; oleocorpos segmentados de 4-10; anfigastros distantes, médio, suborbicular a ovalado, tão espesso quanto o caulídio.

Material examinado: sobre tronco podre, na base, 17/III/1982, Yano 4019(SP 174207); idem, área militar, sobre casca de árvore, 20/III/1982, Yano 4062 (SP 174225).

Comentários: cresce sobre tronco mas também pode ocorrer sobre rochas. Caracteriza-se pela presença de oleocorpos segmentados, anfigastros distantes e aspecto verde-opaco.

Ocorre nos Estados do Acre, Pernambuco, Roraima, Rio de Janeiro e São Paulo; Bahia (Vilas Bôas-Bastos \& Bastos 1998). É a primeira referência para o Paraná.

Lejeunea minutiloba Evans, Bull. Torrey Bot. Club 44: 525. 1927.

Tipo: Ilhas Virginas, St. Thomas (NY). Ilustração: Oliveira e Silva \& Yano (1998).

Gametófitos pequenos, verde-claros, prostrados. Caulídios ramificados, secção transversal, 7 células corticais, 6-12 células medulares de paredes espessas. Filídios contíguos a imbricados, complanados, oblíquos a expandidos. Lobos ovalados, 770 × $62 \mu \mathrm{m}$; margem inteira; ápice obtuso. Lóbulos reduzidos a muito pequenos, 66-67 x $180 \mu \mathrm{m}$. Células centrais ovaladas a hexagonais, 29,0$39,4 \times 25,0-36,0 \mu \mathrm{m}$; marginais $13,7-29,0 \times$ $13,7 \mu \mathrm{m}$, paredes finas e trigônios ausentes. Anfigastros pequenos, distantes $150 \mathrm{x}$ $171 \mu \mathrm{m}$, merófito ventral 2 células larg. Esporófito não observado.

Material examinado: no solo úmido numa pequena elevação, 20/III/1982, Yano 4070 (SP 174229).

Comentários: cresce geralmente como epífila, mas também no solo úmido ou rochas. A espécie se caracteriza pelos lóbulos reduzidos às vezes a uma pequena dobra; anfigastros pequenos, 1,5-2,0 vezes a largura do caulídio.

Ocorre apenas no Paraná e Rio de Janeiro. 
Lejeunea ulicina (Tayl.) Gott., Lindenb. \& Nees, Syn. Hepat: 387. 1945.

Basiônimo: Jungermannia ucilina Tayl., Trans. Bot. Soc. Edinburgh 1: 115. 1844.

Tipo: Ireland, Kenmore, Kerry Country. Ilustrações: Schuster (1980).

Gametófitos prostrados, isolados, amarelados ou verde-amarelados; filídios semelhantes, suberetos a eretos, subovalados; lóbulo fortemente convexo, inflado, ocupando quase todo o filídio; células lisas, paredes finas ou pouco espessadas, trigônios pequenos; anfigastro pequeno, remoto, mais comprido do que largo, oblongo-oval. Perianto não observado.

Material examinado: área militar, epífilas, 20/III/1982, Yano 4060p.p. (SP 174221).

Comentários: cresce sobre substratos lisos como folhas e rochas. Caracteriza-se pelo tamanho pequeno com lóbulos grandes ocupando quase todo o filídio e anfigastros pequenos.

Ocorre nos Estados de São Paulo; Roraima (Santiago 1997, como Microlejeunea). É a primeira referência para o Paraná.

Leptolejeunea exocelata (Spruce) Evans, Bull. Torrey Bot. Club 29: 498. 1902.

Basiônimo: Lejeunea exocelata Spruce, Trans. \& Proc. Bot. Soc. Edinburgh 15: 195. 1884. Tipo: Peru, Tarapoto.

Ilustrações: Bischler (1969).

Gametófitos medianos; filídios contíguos, planos; margem dorsal enrolada irregularmente; filídio elíptico ou abovado, margem inteira; ápice obtuso, trigônios presentes; ocelos ocasionais em diferentes partes da planta; lobo desenvolvido; anfigastros largos, bífidos 2-3 células de tamanho na parte apical, oblíquo.

Material examinado: área militar, epífilas, 20/ III/1982, Yano 4060p.p., 4060ap.p., 4060bp.p. (SP 174221, SP 174222, SP 174223).

Comentários: geralmente encontrada como epífila. Caracteriza-se pelo formato do anfigastro com 2-3 células na parte apical e ocelos ocasionais no filídio.

Ocorre nos Estados do Acre, Amazonas, Paraná, Rio de Janeiro, Santa Catarina e São Paulo.

Lopholejeunea nigricans (Lindenb.) Schiffn., Consp. Hepat. Archip. Ind. 293. 1898.

Basiônimo: Lejeunea nigricans Lindenb., Syn. Hepat. 316. 1845.

Tipo: Java.

Ilustração: Gradstein (1994); Oliveira e Silva (1998).

Gametófitos marrom-escuros a pretos. Caulídio, secção transversal 10-20 células corticais, 15 a muitas células medulares. Filídios distantes, suberetos. Lobo ovalado, $600 \times 400 \mu \mathrm{m}$; margem inteira; ápice arredondado. Lóbulo pequeno, cônico, dente apical inconspícuo. Células marginais isodiamétricas, hexagonais $10-11 \times 10$ $11 \mu \mathrm{m}$, centrais $17-2613-24 \mu \mathrm{m}$, paredes retas, espessadas. Anfigastros distantes, orbiculares, inteiros, 3 vezes larg. do caulídio. Perianto obovado, irregularmente denteado.

Material examinado: sobre tronco de árvore viva, 17/III/1982, Yano 4024 (SP 174210).

Comentários: cresce sobre tronco vivo e pedra em ambiente úmido e sombrio ao longo dos riachos e rios e na margem de florestas úmidas.

A espécie apresenta coloração escura e pode ser diferenciada de Lopholejeunea subfusca pelo perianto emerso e pouco laciniado.

Ocorre nos Estados do Amazonas, Goiás, Minas Gerais, Mato Grosso, Pará, Paraná, Pernambuco, Rio de Janeiro, Santa Catarina e São Paulo.

Mastigolejeunea auriculata (Wils.) Schiffn., Engler \& Prantl, Nat. Pflanzenfam. 1(3): 129. 1893.

Basiônimo: Jungermania auriculata Wils., Drumond Musci Amer. 170. 1841.

Tipo: Estados Unidos, New Orleans.

Ilustrações: Behar et al. (1992); Gradstein (1994). 
Gametófitos marrom-purpúreos ou foscos; filídios imbricados, convoluto quando secos, lobo grande, margem plana, oblongo-ovalado, às vezes falcado, se estendendo até o meio do filídio, células espessadas, trigônios pequenos, 2-3 oleocorpos, anfigastros imbricados, orbiculartruncados no ápice, revolutos. Perianto emergente, obovado.

Material examinado: sobre tronco de árvore viva, 17/III/1982, Yano 3995(SP 174200).

Comentários: cresce sobre tronco. Caracteriza-se pelo formato do lobo grande com margem plana e 2-3 oleocorpos.

Ocorre nos Estados do Amapá, Espírito Santo, Goiás, Mato Grosso, Pará, Paraná e São Paulo.

Rectolejeunea pililoba (Spruce) Schust., The Hepaticae and Anthocerotae of North America, 4: 1153. 1980.

Basiônimo: Lejeunea pililoba Spruce, J. Linn. Soc. Bot. 30: 346. 1895.

Tipo: Dominica, Roseau Valley.

Ilustrações: Schuster (1980); Oliveira e Silva (1998).

Gametófitos verde-claros, medianos; filídios nunca caducos, contíguos ou imbricados, eretos a oblíquos, ovalados a orbiculares margens crenuladas por células salientes; lóbulos reduzidos com um grande dente apical, filiforme, sempre paralelo ao caulídio com uma papila hialina terminal, ocasionalmente pequenos trigônios, parede fina; anfigastro distante, ovalado, lanceolado-acuminado. Perianto ovalado a obcordado, ápice truncado e extenso com uma ponta pequena.

Material examinado: sobre tronco de árvore viva, 17/III/1982, Yano 3973, 4014, 4031 (SP 174192, SP 174206, SP 174213).

Comentários: cresce sobre troncos em lugares úmidos. Caracteriza-se por não apresentar filídios caducos e pelo tamanho do lobo com um grande dente apical filiforme.

Ocorre nos Estados do Paraná, Rio de Janeiro e Sergipe.

\section{Plagiochilaceae}

Plagiochila corrugata (Nees) Nees \& Mont., Ann. Sci. Nat. ser 2.5: 52. 1836.

Basiônimo: Jungermannia corrugata Nees in Martius, Flora Brasil. enum. plant. 1: 378. 1833. Tipo: Minas Gerais, Ouro Preto (Vila Rica), Martius.

Ilustrações: Lemos-Michel (1999).

Gametófitos grandes, verde-amarelados a verde-escuros. Filídios imbricados, mais longos que largos, sub-retangulares; margens superior $\mathrm{e}$ inferior inteiras ou às vezes denteadas e bastante onduladas. Células romboidais, com ou sem trigônios. Esporófito não observado.

Material examinado: sobre tronco de árvore viva, 17/III/1982, Yano 4025(SP 174211).

Comentários: cresce sobre tronco de árvore viva. Os filídios imbricados, com as margens inteiras e bastante ondulada, às vezes apresentam pequenos dentículos esparsos, muito semelhante a $P$. martiana.

Ocorre nos Estados do Espírito Santo, Minas Gerais, Paraná, Rio de Janeiro, Rio Grande do Sul, Santa Catarina e São Paulo.

Plagiochila martiana (Nees) Lindenb., Spec. Hepat. Fasc. 1: 12. 1839.

Basiônimo: Jungermannia martiana Nees, Linnaea 6: 617. 1831.

Tipo: Brasil.

Ilustrações: Oliveira e Silva (1998).

Gametófitos verde-claros, às vezes esbranquiçados. Ramos 2-3 x 2-5mm, simples. Filídios densamente imbricados, expandidos quando úmidos, ovalados $1,0 \times 0,5 \mathrm{~mm}$, margens sem dentes a ligeiramente onduladas; ápice obtuso; base ventral longamente decurrente sobre o caulídio, dorsal curtamente decurrente; células arredondadas a alongadas $15-18 \times 7-10 \mu \mathrm{m}$ as marginais, $21-24 \times 27-30 \mu \mathrm{m}$ as centrais; trigônios triangulares, sem espessamentos intercelulares. Anfigastros ausentes. Esporófito não observado.

Material examinado: sobre tronco podre 
caído na mata, 17/III/1982, Yano 4007 (SP 174202); idem, sobre tronco de árvore, $17 /$ III/1982, Yano 4023 (SP 174209); idem, sobre tronco de árvore viva, 20/III/1982, Yano 4072 (SP 174230).

Comentários: a espécie cresce sobre tronco vivo, podre e caracteriza-se pela margem do filídio sem dentes e os filídios são densamente imbricados.

Ocorre em Pernambuco, Minas Gerais, São Paulo, Rio Grande do Sul e Rio de Janeiro. É a primeira referência para o Paraná.

Radulaceae

Radula complanata (L.) Dum., Jungerm. Europ.: 38. 1831.

Basiônimo: Jungermannia complanata L., Spec. plant. 2: 1133. 1753.

Tipo: In Europa.

Ilustrações: Schuster (1980).

Gametófitos prostados, verde-amarelados, brilhantes; filídios distintamente imbricados e sempre falcados, ovalados; lobo subquadrado, grande, preso ao caulídio, côncavo; células com paredes finas e pequenos trigônios; oleocorpo único, grande em forma ovóide a elíptico-granuloso. Perianto oblongo-cônico.

Material examinado: sobre tronco de Tiliaceae, 17/III/1982, Yano 3964(SP 174187); idem, sobre tronco de árvore viva, 17/III/1982, Yano 3981 (SP 174195); idem, sobre tronco de árvore viva, 20/III/1982, Yano 4073 (SP 174231); idem, sobre casca de arbusto, 20/III/ 1982, Yano 4078 (SP 174233).

Comentários: cresce sobre tronco, principalmente na base. Esta espécie possui características muito semelhantes a outras espécies de Radula. Mas, Schuster (1980) explica que Radula complanata pode ser distinta das outras por ser a única Radula paróica, as outras são todas dióicas.

Ocorre nos Estados do Amapá, Minas Gerais e Rio de Janeiro. É a primeira referência para o Paraná.
Ricciaceae

Riccia plano-biconvexa Steph., Bih. Kongl. Svenska Vetensk Akad. Handl. 23(III,2): 29. 1897. Tipo: Brasil, Rio Grande do Sul, Cachoeira (G 8975).

Ilustrações: Vianna (1985).

Gametófitos densos, verde-amarelados, recobertos por escamas negras, brilhantes quando secas, dicótomas, divergente em ângulos de $35^{\circ}-70^{\circ}$, ápice obtuso, sulco mediano profundo no ápice marcado até a base, superfícies laterais fortemente convexas no ápice, face ventral com forte espessamento mediano que progressivamente diminui em direção aos bordos; células alongadas; escamas hialinas a vermelho-violeta, até negras, ultrapassando um pouco a margem do talo, bordos lobados.

Material examinado: sobre pedras sedimentares, 17/III/1982, Yano 3988 (SP 174198); idem, na camada fina de húmus sobre pedras, 17/III/1982, Yano 3994 (SP 174199).

Comentários: cresce diretamente sobre rocha ou sobre húmus. Caracteriza-se pela presença de divisões dicotômicas divergentes por ângulos de $35^{\circ}-70^{\circ} \mathrm{e}$ as margens lobadas.

Ocorre nos Estados de Alagoas, Bahia, Espírito Santo, Goiás, Mato Grosso, Pernambuco, Rio Grande do Norte, Rio Grande do Sul (JovestAst 1991). É a primeira referência para o Paraná.

Nas 119 amostras coletadas foram encontradas o total de 65 espécies, das quais 26 são novas ocorrências para o Estado e uma referência nova para o Brasil (Erythrophyllastrum andinum (Sull.) Zand.). Somente algumas espécies características de áreas alteradas foram encontradas, como Lejeunea glaucescens e Sematophylllum caespitosum por exemplo, que aparecem bem representadas. As famílias com maior número são representadas por Lejeuneaceae com 15 espécies, seguida de Fissidentaceae com cinco, Meteoriaceae, Frullaniaceae e Bryaceae com quatro. Pelos re- 
sultados obtidos, observa-se que a área coletada não estava em processo de degradação, pois a relação número de amostras coletadas e número de espécies encontradas é baixo, indicando alta diversidade. Isto demonstra que há necessidade de coletas de material briofítico em áreas remanescentes de diferentes ecossistemas e preservá-los, para manter a diversidade das espécies no Brasil. Esta diversidade tem sido referida desde o primeiro catálogo de Yano (1981), seguido de Yano (1984b, 1989, 1995) que relacionam mais de 3.000 espécies de briófitas brasileiras. Este número tem crescido à medida que são feitos os trabalhos de levantamento em diferentes áreas e ecossistemas.

\section{Referências Bibliográficas}

Bartram, E. B. 1949. Mosses of Guatemala. Fieldiana Botany 25: 1-442.

Bastos, C. J. P. \& Yano, O. 1993. Musgos da zona urbana de Salvador, Bahia, Brasil. Hoehnea 20(1/ 2): 23-33.

Behar. L.; Yano, O. \& Vallandro, G. C. 1992. Briófitas da restinga de Setiba, Guarapari, Espírito Santo. Boletim do Museu de Biologia Mello Leitão, n. ser. 1: 25-38.

Bischler, H. 1969. Le genre Leptolejeunea (Spruce) Steph. en Amerique. Nova Hedwigia 27: 265-350.

Buck, W. R. \& Ireland, R. R. 1985. A reclassification of the Plagiotheciaceae. Nova Hedwigia 41: 89125.

Castro, N. M. F. C. F. 1997. Bryopsida do Parque Nacional de Sete Cidades, Piauí, Brasil. Dissertação de Mestrado. Universidade Federal de Pernambuco, Recife.

Costa, D. P. \& Yano, O. 1998. Briófitas da restinga de Macaé, Rio de Janeiro, Brasil. Hoehnea 25(2): $99-$ 119.

Crum, H. A. \& Anderson, L. E. 1981. Mosses of Eastern North America. 2 vols. Columbia, University Press, New York.

Florschütz, P. A. 1964. The Mosses of Suriname. E. J. Brill, Leiden.

Frahm, J.-P. 1991. Dicranaceae: Campylopodioideae, Paraleucobryoideae. Flora Neotropica, monograph 54: 1-238.

Fulford, M. 1976. Manual of the leafy Hepaticae of Latin America 4. Memoirs of the New York Botanical Garden 11(4): 393-535.
Gier, J. L. 1980. A preliminary study of Thuidiaceae (Musci) of Latin America. Journal of Bryology 11: 253-309.

Gradstein, R. S. 1994. Lejeuneaceae: Ptychantheae, Brachiolejeuneae. Flora Neotropica, monograph 62: $1-216$.

Hell, K. G. 1969. Briófitas talosas dos arredores da cidade de São Paulo (Brasil). Editora da Universidade de São Paulo, São Paulo, Botânica 25.

Hirai, R. Y.; Yano, O. \& Ribas, M. E. G. 1998. Musgos da Mata Residual do Centro Politécnico (Capão da Mata de Educação Física), Curitiba, Paraná, Brasil. Boletim do Instituto de Botânica 11: 81118.

Lemos-Michel, E. 1980. O gênero Frullania (Hepaticopsida) no Rio Grande do Sul, Brasil. Dissertação de Mestrado. Univiversidade Federal do Rio Grande do Sul, Porto Alegre.

Lemos-Michel, E. 1999. Briófitas epífitas sobre Araucaria angustifolia (Bert.) Kuntze no Rio Grande do Sul, Brasil. Tese de Doutorado. Universidade de São Paulo, São Paulo.

Lemos-Michel, E. \& Yano, O. 1998. O gênero Bryopteris (Hepatophyta) no Brasil. Acta Botanica Brasilica 12(1): 5-24.

Lisboa, R. C. L. 1993. Musgos acrocárpicos do Estado de Rondônia. Museu Paraense Emílio Goeldi, Belém.

Manuel, M. G. 1977. A monograph of the genus Zelometeorium Manuel gen. nov. (Bryopsida: Meteoriaceae). The Journal of the Hattori Botanical Laboratory 43: 107-126.

Ochi, H. 1980. A revision of the neotropical Bryoideae, Musci (First Part). The Journal of the Facculty of Education Tottori University, Natural Science 29(2): 49-154.

Oliveira e Silva, M. I. M. N. 1998. Briófitas da Reserva Ecológica de Rio das Pedras, município de Mangaratiba, do Parque Estadual da Illha Grande e da Reserva Biológica Estadual da Praia do Sul, município de Angra dos Reis, Estado do Rio de Janeiro. Tese de Doutorado. Universidade de São Paulo, São Paulo.

Oliveira e Silva, M. I. M. N. \& Yano, O. 1998. Ocorrências novas de briófitas para o Brasil. Revista Brasileira de Botânica 21(2): 125-134.

Jovet-Ast, S. 1991. Riccia (Hépatiques, Marchantiales) d'Amérique Latine - taxons du Sous-Genre Riccia. Cryptogamie, Bryologie-Lichénologie 12(3): 189 378.

Santiago, R. L. 1997. Estudo brioflorístico de três formações vegetais no município de Bonfim, Roraima. Dissertação de Mestrado. Universidade Federal de Pernambuco, Recife. 
Sehnem, A. 1969. Musgos sul-brasileiros. Pesquisas, série Botanica 27: 1-36.

Schuster, R. M. 1980. The Hepaticae and Anthocerotae of North America. vol. 4. Columbia University Press, New York.

Schuster, R. M. 1984. Evolution, phylogeny and classification of the Hepaticae. In: R. M. Schuster (Ed.), New Manual of Bryology. Hattori Botanical Laboratory, Miyazaki 2: 892-1092.

Sharp, A. J.; Crum, H. \& Eckel, P. M. 1994. Flora of México. Memoirs of the New York Botanical Garden 69(1, 2): 1-1113.

Slageren, M. W. van. 1985. A taxonomic monograph of the genera Brachiolejeunea and Frullanoides (Hepaticae) with a SEM analysis of the sporophyte in the Ptychanthoideae. Netherlands, Krips ReproMeppel.

Stotler, R. \& Crandall-Stotler, B. 1974. A monograph of the genus Bryopteris (Swartz) Nees von Esenbeck. Bryophytorum Bibliotheca 3: 1-159.

Tixier, P. 1985. Contribution à la connaissance des Cololejeunoideae. Bryophytorum Bibliotheca 27: 1-439.

Vanden Berghen, C. 1976. Frullaniaceae (Hepaticae) Africanae. Bulletin du Jardin Botanique National de Belgique 46: 1-220

Vianna, E. C. 1985. Marchantiales. Flora ilustrada do Rio Grande do Sul 15. Boletim do Instituto Central de Biociências, Porto Alegre 38: 1-213.

Vilas Bôas-Bastos, S. B. \& Bastos, C. J. P. 1998. Briófitas de uma área de cerrado no município de Alagoinhas, Bahia, Brasil. Tropical Bryology 15: 101-110.

Vitt, D. H. 1984. Classification of Bryopsida. In: R. M. Schuster (Ed.), New Manual of Bryology. Hattori Botanical Laboratory, Miyazaki 2: 696-759.
Yano, O. 1979. Contribuição ao inventário dos Musci brasileiros: Helicophyllaceae. Rickia 8: 7-16.

Yano, O. 1981. A checklist of the Brazilian Mosses. The Journal of the Hattori Botanical Laboratory 50 : 279-456.

Yano, O. 1984a. Brífitas. Pp. 27-30. In: O. Fidalgo \& V. L. R. Bononi (Coords.), Técnicas de coleta, preservação e herborização de material botânico. Manual 4 . Instituto de Botânica, São Paulo.

Yano, O. 1984b. Checklist of the Brazilian liverworts and hornworts. The Journal of the Hattori Botanical Laboratory 56: 418-548.

Yano, O. 1989. An additional checklist of Brazilian bryophytes. The Journal of the Hattori Botanical Laboratory 66: 371-434.

Yano, O. 1992a. Leucobryaceae (Bryopsida) do Brasil. Tese de Doutorado. Universidade de São Paulo, São Paulo.

Yano, O. 1992b. Briófitas da Ilha de Maracá, Roraima, Brasil. Acta Amazonica 22(4): 535-539.

Yano, O. 1995. A new additional annotated checklist of Brazilian bryophytes. The Journal of the Hattori Botanical Laboratory 78: 137-182.

Yano, O. \& Bastos, C. J. P. 1994/95. Musgos do Estado da Bahia, Brasil. Biologica Brasilica 6(1/2): 926.

Yano, O. \& Oliveira e Silva, M. I. M. N. 1997. Criptógamos do Parque Estadual das Fontes do Ipiranga, São Paulo, SP. Briófitas, 2: Fissidentaceae (Bryales). Hoehnea 24(2): 107-114.

Yano, O.; Marinho, M. G. V. \& Mariz, G. 1987. Novas ocorrências de briófitas no nordeste brasileiro. Rickia 14: 73-87.

Zander, R. H. 1993. Genera of the Pottiaceae: mosses of harsh environments. Bulletin of the Buffalo Society National Sciences 32: 1-378. 